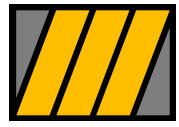

ESCUELA DE NEGOCIOS

Universidad Torcuato Di Tella

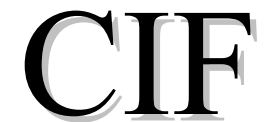

Centro de Investigación en Finanzas

Documento de Trabajo 03/2003

\title{
Living and Dying with Hard Pegs: The Rise and Fall of Argentina's Currency Board
}

Augusto de la Torre

World Bank

Eduardo Levy Yeyati

Universidad Torcuato Di Tella

Sergio Schmukler

World Bank
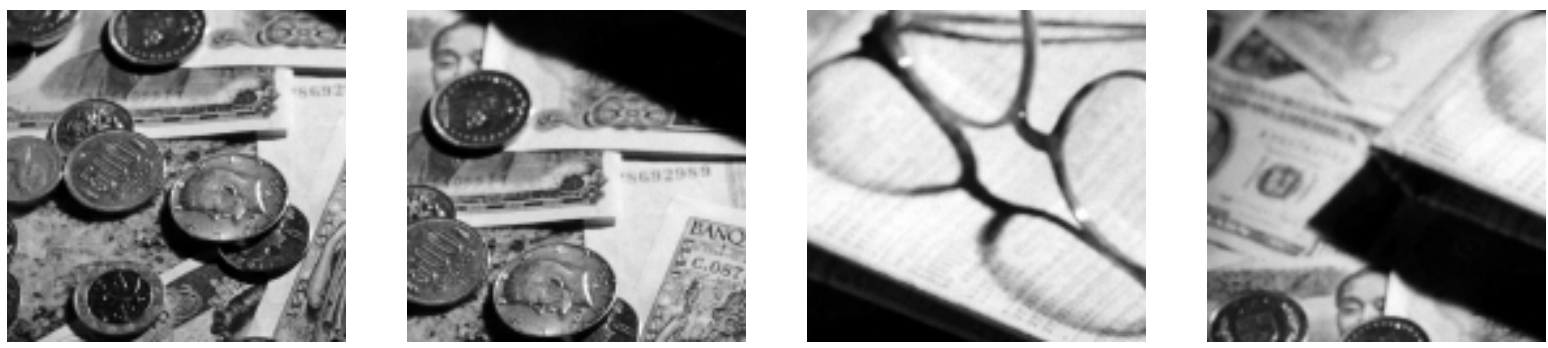

Miñones 2177, C1428ATG Buenos Aires • Tel: 4784.0080 interno 181 y 4787.9394 • Web site: www.utdt.edu/departamentos/empresarial/cif/cif.htm 


\title{
Living and Dying with Hard Pegs: The Rise and Fall of Argentina's Currency Board ${ }^{\otimes}$
}

\author{
Augusto de la Torre \\ World Bank \\ Eduardo Levy Yeyati \\ Universidad Torcuato Di Tella \\ and \\ Sergio L. Schmukler \\ World Bank
}

January 15, 2003

\begin{abstract}
The rise and fall of Argentina's currency board illustrates the extent to which the advantages of hard pegs have been overstated. The currency board did provide nominal stability and boosted financial intermediation, at the cost of endogenous financial dollarization, but did not foster fiscal or monetary discipline. The failure to adequately address the currency-growth-debt trap, into which Argentina fell at the end of the 1990s, precipitated a run on the currency and the banks, followed by the abandonment of the currency board and a sovereign debt default. The crisis can be best interpreted as a bad outcome of a high-stakes strategy to overcome a weak currency problem. To increase the credibility of the hard peg, the government raised its exit costs, which deepened the crisis once exit could no longer be avoided. But some alternative exit strategies would have been less destructive than the one adopted.
\end{abstract}

Keywords: exchange rate regime; currency board; dollarization; floating; currency crisis; banking crisis; convertibility

JEL classification: E44, F30, 31, F33, F36, F41, G21, G28

\footnotetext{
${ }^{\otimes}$ Authors are Senior Financial Sector Advisor, Latin American and the Caribbean Region, Professor, and Senior Economist, Development Research Group, respectively. An earlier version of this paper was circulated as "Argentina's Financial Crisis: Floating Money, Sinking Banking." We are grateful to Alberto Ades, Javier Bolzico, Jerry Caprio, José De Gregorio, Graciela Kaminsky, Paul Levy, Sole Martinez Peria, Guillermo Perry, Andrew Powell, Roberto Rigobón, Luis Servén, Federico Sturzenegger, Ted Truman, Andrés Velasco (the editor), Charles Wyplosz, as well as participants at seminars held at Columbia University, the LACEA Annual Meeting (Madrid), and Universidad Torcuato Di Tella for helpful comments. We thank Tatiana Didier, Mariano Lanfranconi, Ana Maria Menendez, Josefina Rouillet, and particularly Marina Halac for excellent research assistance. We thank Laura D'Amato, Fernanda Martijena, and Maria Augusta Salgado for help with the data. The views expressed in this paper are entirely those of the authors and do not necessarily represent the views of the World Bank. E-mail addresses: adelatorre@worldbank.org, ely@utdt.edu, and sschmukler@worldbank.org.
} 


\section{Introduction}

The rise and fall of Argentina's currency board (a textbook model of a rigid exchange rate regime for more than 10 years) and the subsequent financial system collapse yield important lessons for the debate on exchange rate regimes for developing countries. ${ }^{1}$ As expected, the Argentine case has already generated an extensive debate on the causes and policy implications of the crisis. ${ }^{2}$ Current explanations, however, concentrate too much on the latest years and do not pay enough attention to the underpinnings of the currency board and to its implications for the financial system and the economy at large.

In this paper, we study the Argentine experience from a perspective that links money (in its function as store of value) and financial intermediation. This approach has important advantages. By organizing the discussion of the different intervening factors around a main motive, it allows us to balance the broadness of a comprehensive survey with the focus needed to extract fairly general lessons. More importantly, it enables us to highlight the role played by the currency board in the development of the financial sector during the 1990s and in the genesis of its collapse. It also allows us to better understand the nature of the currency-growth-debt (CGD) trap into which Argentina fell during the late 1990s, and how it eventually led to a currency and bank run that precipitated a devastating economic crisis.

In light of the Argentine experience, we argue that the benefits of hard pegs have been much overstated. To be sure, by providing savers with the dollar as the store of value (directly under dollarization, or via the peg under currency boards), a credible hard peg ensures nominal stability and boosts financial intermediation. But even if credible, a hard peg does not automatically lead to the emergence of alternative nominal flexibility (particularly in wages, fiscal spending, and financial contracting) to compensate for the loss of the nominal exchange rate as a policy instrument. This is particularly problematic in the case of hard peg countries that, like Argentina, do not meet the classical conditions for an optimal currency (dollar) area. Partly as a result, hard pegs do not per se induce fiscal or even monetary discipline. The monetary framework of a hard peg, although typically protected by a heavy legal and institutional armor, can be dismantled more easily than expected through the emergence of quasi-monies in response to extreme budgetary cash flow pressures coupled with insufficient nominal flexibility in fiscal spending and public sector wages. Moreover, with its credibility being a positive function of its exit costs, a hard peg creates powerful incentives for the government to raise exit costs further (re-double the bet) when the hard peg is under pressure. A particular way in which hard pegs endogenously raise exit costs is by fostering dollarization, including of the liabilities of debtors in the non-tradable sector-as the government would rather not adopt measures to explicitly discourage dollarization for fear of undermining the credibility of its commitment to the hard peg.

\footnotetext{
${ }^{1}$ See Frankel et al. (2001) for a brief history of this debate.

${ }^{2}$ See among others, Feldstein (2002), Calvo, Izquierdo, and Talvi (2002), Perry and Servén (2002), Mussa (2002), Hausmann and Velasco (2002), and Powell (2002).
} 
Exiting a hard peg is inherently a very painful affair, given the contradiction between hardening the peg and allowing for a smooth exit. But some ways of exiting can be more disastrous than others. We analyze the Argentine experience to draw lessons on alternative exit strategies. With the benefit of hindsight and the caveats of any counterfactual analysis, we argue that the forcible pesification of existing financial contracts ("stock pesification") was the most costly choice, for it was bound to cause an excessive destruction of property rights with long-lasting consequences for financial intermediation and, by creating a massive peso overhang in the midst of a currency run, was likely to rekindle the deposit flight and exacerbate the exchange rate overshooting. By contrast, an early (before 2001) exit into full dollarization (of financial contracts and money in circulation) might have averted the bank run, thus protecting financial intermediation and the payment system, but would have done nothing to mitigate the deflationary and recessionary costs of a protracted adjustment of the real exchange to a more depreciated equilibrium level. In this light, we find support for an intermediate exit option: dollarization of existing financial contracts ("stock dollarization") to respect the widespread use of the dollar as store of value, combined with "pesification at the margin" (for instance, via the consolidation of the existing pesos and quasi-monies into a new national currency) to exploit the use of the peso as means of payment and unit of account, which remained extensive and resilient throughout the convertibility period and even during the run. ${ }^{3}$ While this alternative would not have spared Argentina from significant banking system stress and even some individual bank failures, as debtors in the nontradable sector would have seen their balance sheets and payment capacity adversely affected by the real exchange rate correction, it might have provided a margin of nominal flexibility while avoiding a systemic financial collapse and the unnecessary destruction of property rights.

Within the terms of the exchange rate debate, the failure of the Argentine currency board is sure to elicit two reactions. On the one hand, bipolar proponents may conclude that currency boards are not hard enough and that sustainable pegs have to go all the way to formal dollarization. On the other, hard peg critics may interpret the case as evidence that the regime debate has been settled in favor of fully floating regimes. We argue that a one-dimensional emphasis on pure fix versus float dilemma is insufficient and can even be misleading. It would be more productive to focus on the weak currency problem that plagues most emerging economies and on the need to build healthy links between money (in its function as store of value) and financial intermediation, while establishing adequate flexibility, including in financial contracting, to facilitate adjustment to shocks. ${ }^{4}$

\footnotetext{
${ }^{3}$ It is useful to state at this point that we do not favor re-dollarization of contracts once the costs of pesification have been largely incurred, as a previous version of the paper might have mistakenly led to believe (see, among others, The Economist 2002).

${ }^{4}$ Underscoring this view is the need for institutional building irrespective of the exchange rate regime of choice. The case of Argentina clearly illustrates the difficulties of importing monetary institutions through the adoption of a peg. We conjecture that these difficulties would not have been bypassed by unilateral dollarization.
} 
The rest of the paper is organized as follows. Section 2 analyzes the rise and fall of convertibility, distinguishing between the good times of financial deepening that were, nonetheless, accompanied by persistent and rising financial dollarization, and the bad times that witnessed the fall of the Argentine economy into a CGD trap from which it could not break free, and the resulting meltdown, triggered by a massive run on the currency that evolved into a deposit run. Section 3 draws lessons from the Argentine experience on hard pegs: their limitations as commitment mechanisms, their specific prudential concerns, and the alternative exit strategies. Section 4 offers some final remarks.

\section{The rise and fall of Argentina's currency board}

It was never a mystery that the rigid peg of the peso to the dollar under convertibility was a highly inconvenient choice from the point of view of Argentina's trade and productive structure. In effect, Argentina is far from meeting the conditions for an optimal currency (dollar) area. It is subject to typically different shocks than the U.S., it has a substantial share of its foreign trade with countries whose currencies fluctuate visà-vis the U.S. dollar and, as a relatively closed economy with a large non-tradable sector, could benefit much more (compared to open economies with relatively small nontradable sectors) from nominal exchange rate adjustments to correct for misalignments in the relative price of tradables to non-tradables.

Convertibility was chosen in Argentina despite the mentioned reasons and not even in light of long-term growth considerations. It was a decision understandably driven by overriding monetary and financial considerations. Convertibility in fact arose as an extreme response to hyperinflation and the consequent implosion of financial intermediation that had taken place in the 1980s, and against a much longer history of repeated episodes of debasement of the domestic currency and fiscal mismanagement.

From its introduction in April 1991, however, convertibility was much more than a simple peg or an expedient exchange rate arrangement to conquer inflation. For starters, the peg was embedded in a broader monetary arrangement that featured, at its heart, a money issuance rule that legally precluded the creation of pesos not backed by hard dollars, except within a very limited range. ${ }^{5}$ Convertibility was intended to produce a nonreversible break away from monetary and financial instability. It was expected to mark for the Argentine psychology a point of no return and a one-way path forward, much like Hernán Cortez's decision to burn the ships had marked for his crew. Moreover, convertibility was from the outset envisioned to have implications well beyond the pure monetary sphere, for it aspired to become an institutional axis that would help put order in other institutions and align incentives among agents, particularly in the economic sphere (fiscal process, bank regulation, labor markets, etc.) but also in the social and political spheres. Convertibility indeed became a central component of the

\footnotetext{
5 The law allowed for up to one-third of disposable international reserves to be constituted with internationally traded, dollar-denominated Argentine sovereign bonds, valued at market prices. This proviso enabled a very limited role for the central bank as lender of last resort-it could create and provide peso liquidity to the banking system in exchange for sovereign Argentine bonds, rather than hard dollars.
} 
social contract, a key institution in the economic and political life of the country. Convertibility was not a contract like any other; it was rather a core or master contract, one upon which other (financial and non-financial) contracts depended.

Mr. Cavallo, Minister of Economy of Argentina at the beginning and at the end of the convertibility decade (1991-2001), used to insist that there was, by design, only one way to exit convertibility in accordance to the law-that is, once the Argentine peso had established itself as an international currency, and a strong one at that. In effect, the convertibility law stated that the central bank would stand ready to buy and sell dollars at no more than one peso per dollar. By implication, the central bank could eventually buy dollars at less than one peso per dollar. Obviously, the catastrophic manner in which convertibility collapsed in January 2002 was a far cry from the glorious exit that had been envisioned by its framers in April 1991.

What explains this massive departure of reality from vision? In the remainder of this section we attempt an explanation. Convertibility did deliver broadly according to promise with respect to the deepening of the financial system, although at the cost of a persistent and rising level of financial dollarization. ${ }^{6}$ In contrast, convertibility failed to deliver with respect to the expectation that, being a permanent monetary "straightjacket," it would, by itself, discipline the fiscal process and induce reforms that would endow Argentina with adequate nominal flexibility (particularly in fiscal spending and wages) to compensate for the absence of nominal exchange rate flexibility. Such a failure became particularly taxing after 1998, as the country was increasingly caught in what we label a currency-growth-debt (CGD) trap that ultimately precipitated the collapse.

\subsection{Good times: financial deepening and increased dollarization}

Out of the ashes left by hyperinflation and financial disarray in Argentina in the 1980s, the one-peso-one-dollar rule of convertibility quickly restored the function of money as a store of value, thereby enabling a rapid regeneration of financial intermediation as reflected a steep growth of bank deposits and loans throughout 1999 (Figure 1)..$^{7}$ Moreover, the rapid taming of inflation brought about by convertibility greatly enhanced the political viability of a number of first generation reforms that the nominal instability of the past had rendered infeasible. Rapid changes thus swept the Argentine economy in the first phase of convertibility, particularly with the restructuring of the external debt (under the Brady Plan), a tax reform centered on the VAT, a series of privatizations, social security reform, and the deregulation of financial markets. This, combined with a wave of capital flows to emerging economies in which Argentina shared

\footnotetext{
${ }^{6}$ By financial dollarization we refer to the holding by residents of foreign currency-denominated assets and liabilities. As argued in Ize and Levy Yeyati (2002), financial dollarization reflects mostly an asset substitution phenomenon (that is, the use of a foreign currency as store of value), as opposed to currency substitution (that is, the use of the foreign currency as unit of account and means of payment).

${ }^{7}$ After a major step increase between 1991 and 1994, banks deposits continued rising steadily from 17 percent of GDP by the end of 1994 to 26 by the end of 1998. Calomiris and Powell (2001) compellingly show that convertibility is indeed key to understanding the rapid growth and strengthening of the financial system in the 1990s.
} 
prominently, fueled aggregate demand and boosted GDP growth to a brisk average of 6.4 percent per annum during 1991-1998 (9.1 percent during 1991-1994), well above the Latin American average of 3.7 percent in 1991-1998 (4.3 percent in 1991-1994).

The sustainability of convertibility's early successes was transitorily but severely questioned during the Mexican (Tequila) crisis of 1995. The Tequila contagion led to a major run on the Argentine peso and bank deposits. Deposits fell by almost 20 percent in a span of few weeks, nearly bringing down the financial system and convertibility with it. This crisis marked a turning point in financial sector policy. The authorities responded by affirming convertibility, while recognizing that its viability required a particularly resilient financial system given the limits imposed by the currency board on the central bank to act as lender of last resort. They launched a series of ambitious financial sector reforms to give effect to this conviction, as illustrated in Appendix Table 1.

The results were impressive according to any standard. ${ }^{8}$ The banking system consolidated and became internationalized, while many public banks were privatized (see Table 1). By the end of the 1990s, a resilient banking system was the crown jewel of convertibility-induced reform. Convertibility did not lead to strong fiscal institutions, ${ }^{9}$ but few doubted that it had led to a shock-resistant banking sector.

The banking system was arguably in a very solid position before the Brazilian devaluation of January 1999, and was still reasonably healthy through the end of 2000, despite the post-1998 continued economic contraction. In effect, common indicators of financial health, shown in Table 2, depict a well capitalized, strongly provisioned, and highly liquid banking system through the year 2000, although a system experiencing losses and increasingly burdened by bad loans after $1998 .{ }^{10}$

The Tequila aftermath affirmed convertibility as a central piece in the social contract, with post-1994 reforms creating a banking system that, though costly, appeared convertibility-compatible in most respects. Towards the end of the decade, the financial system's prudential buffers were sufficient to withstand sizeable liquidity and solvency shocks-including a flight of about one-third of the deposits as well as further significant

\footnotetext{
${ }^{8}$ So much that by 1998 Argentina ranked second (after Singapore, tied with Hong Kong, and ahead of Chile) in terms of the quality of its regulatory environment, according to the CAMELOT rating system developed by the World Bank. This system combined separate rankings for capital requirements (C); loan loss provisioning requirements and definition of past-due loans (A); management (M), defined by the extent of high-quality foreign bank presence; liquidity requirements $(\mathrm{L})$; operating environment $(\mathrm{O})$ as measured by rankings with respect to property rights, creditor rights, and enforcement; and transparency $(\mathrm{T})$, as measured by whether banks are rated by international risk rating agencies and by an index on corruption. Argentina ranked first for C (tied with Singapore), fourth for A, third for M, fourth for L, seventh for O, and second for T. For details see World Bank (1998), pp. 39-61 and Appendix A.

${ }^{9}$ See Gavin and Perotti (1997) and Tornell and Velasco (2000).

${ }^{10}$ Profits turned negative already in 1998 and became deeply negative during 1999-2000 partly because of the need to constitute provisions in the face of rising bad loans. NPLs rose to 11.6 percent of total loans in 2000, from 10.5 percent the year earlier (Table 2).
} 
decay in the loan portfolio-without endangering convertibility. ${ }^{11}$ The important presence of reputable foreign banks (they accounted for over 70 percent of total banking assets in 2000, as shown in Table 1) was broadly perceived to implicitly augment these liquidity and solvency cushions. These banks were expected to stand behind the capital and liquidity of their affiliates in Argentina, at least in the context of bad states of the world associated with bad luck. (Few were thinking then of bad states of the world caused directly by confiscatory government policy.)

The remarkable strengthening of the banking system was accompanied by a persistent and rising level of financial dollarization. This phenomenon was not part of the intention of the framers of convertibility. But it was an almost inevitable corollary of policy incentives created by convertibility itself coupled with a stubborn market perception of exchange rate risk that convertibility could not remove, despite its heavy institutional and legal armor.

The founders of convertibility envisioned a strong peso as the way for an elegant and almost natural exit from the one-peso-one-dollar rule. Such an aspiration, however, could not be easily translated into measures to discourage financial dollarization. This was because of the risk that such measures be interpreted by the market as an indication that the authorities themselves did not think that the one-peso-one-dollar rule was to endure under most states of the world. Hence, the authorities faced incentives not to adopt prudential norms (e.g., loan classification and provisioning rules, liquidity requirements) that would explicitly discourage the use of the dollar in financial contracts. $^{12}$ Similarly, the government did not issue peso debt in domestic markets not just because dollar debt was less costly, but also because incurring the additional cost could only have been interpreted as a hedge against a future devaluation, undermining the confidence in the one-to-one rule that convertibility was meant to inspire.

At the same time, markets did not fully take to heart the mantra of "no more than one peso for one dollar, forever." Instead, they continued to attach a nontrivial probability to the risk of a nominal devaluation of the peso. This perceived currency risk was a key factor behind a peso problem that persisted throughout the 1990s, spiking during turbulent times, as shown in Figure 2. ${ }^{13}$

The lasting perception of a residual risk of nominal devaluation, together with the mentioned incentives faced by the authorities (which resulted in an essentially currencyblind prudential framework), constitute an important part of the explanation of the rise in

\footnotetext{
${ }^{11}$ Table 2 puts systemic core liquidity (disposable international reserves of the central bank plus foreign exchange in cash or near-cash held abroad by banks) at about 39 percent of banking system deposits at end2000. However, there was a significant variance in the distribution of such liquidity across banks. This may explain why the "corralito" was imposed at the end of 2001 before deposits had fallen by 30 percent.

${ }^{12}$ We come back to this point in the next section.

${ }^{13}$ The interest rate differential reflected not only exchange rate risk, but also default risk as discussed in Broda and Levy Yeyati (2001) and Schmukler and Servén (2002).
} 
financial dollarization throughout the convertibility decade. ${ }^{14}$ Dollarization permeated both private and public sector financial assets and liabilities, and was very significant in loans to the non-tradable sector. Figure 2 shows the steady rise in the share of dollar credit in total credit to the private and public sectors. The first panel of Figure 3 shows that dollarization of mortgage loans (that is, loans to an important non-tradable sector) increased significantly since 1994, while the second panel of the same figure shows that dollar debt, as indicated by firms' balance sheets, was even higher for non-tradable firms than for tradable ones.

Dollarization of public sector debt also rose significantly, and not just in terms of bank credit to the public sector. In particular, the public debt made explicit as a result of the reform in the social security system was denominated in dollars. At the same time, certain other policies taken by the public sector encouraged real dollarization-for instance, the decision to allow public utility tariffs to be denominated in dollars (done to reassure a dollar income to the privatized utility companies, thus recognizing that convertibility was not fully credible in the view of such companies).

Financial dollarization in Argentina reflected an asset substitution phenomenon (a shift to the dollar as a store of value), and was accompanied by currency substitution (a shift to the dollar as a unit of account and means of payment) only to a minor degree. Dollar pricing was limited mostly to internationally traded goods and big-ticket items such as real estate, and use of the dollar for everyday transactions was rather marginal, as reflected in marked differences in dollarization ratios for different types of bank deposits (Figure 4). Time deposits became increasingly dollarized during convertibility. In contrast, the degree of dollarization of passbook saving accounts, albeit high (about 40 percent), remained relatively stable throughout the 8 years ending in 2000. Moreover, the degree of dollarization of demand deposits was strikingly low (well under 10 percent) and stable during most of the decade. ${ }^{15}$

To be sure, the authorities tried an indirect avenue to deal with the currency risk associated with financial dollarization through prudential norms-namely the interest rate factor. $^{16}$ As explained in Appendix Table 1 and shown in Table 3, regulatory capital requirements for credit risk were not only determined in line with the typical Basle-type procedure of applying higher weights to riskier loan classes. They also tried to take into account the risk of individual loans within each loan class. This was operationalized by increasing the weight applied to individual loans that charged higher interest rates-i.e., by adding a so-called interest rate factor. The underlying assumption was that if banks price risks correctly, these should be fully reflected in the lending interest rate. The norm

\footnotetext{
${ }^{14}$ The peso problem was not independent of the degree of financial dollarization, as explained at the end of this section.

${ }^{15}$ The evidence of a resilient transactional demand for pesos was ultimately confirmed by the stability of real peso balances following the abandonment of convertibility, as we show below. Even after the corralito was lifted in December 2002, M1/GDP remained slightly above its historical levels. The distinction between currency and asset substitution will play a crucial role when we come back to the exit strategy problem in the next section.

${ }^{16}$ We thank Andrew Powell for raising this point.
} 
was initially designed to take into account different interest rate scales and thresholds depending of the currency of loan denomination (Table 3). This innovative system was probably effective in capturing some risk differences across loans, but failed at capturing the specific risk of dollar loans to the non-tradable sector (a point further discussed in Section 3). Rather, the interest rate factor may have encouraged dollarization because it was in fact higher for peso loans than for dollar loans, given that the peso problem entailed systematically higher peso interest rates (Figure 5). Moreover, in 1999, when currency risk became a source of policy concern, the differentiation in the interest rate factor according to the currency of loan denomination was eliminated-yet another example of the contradictions inherent in the convertibility game of continuously raising the stakes.

At any rate, the increasing level of financial dollarization further affirmed the onepeso-one-dollar but at the expense of the peso-i.e., by departing from the admittedly unrealistic vision of a strengthening peso that, as noted earlier, was held by the convertibility framers. As financial dollarization persisted and increased, it also became clearer that a disorderly breakdown of the one-peso-one-dollar rule would be an unmitigated catastrophe-it would wreck the solvency of debtors in the non-tradable sector and, hence, of the banking system. As such, dollarization was not an undesirable side effect but rather a crucial ingredient in the convertibility scheme: by increasing the exit costs, it reinforced the "burning-of-the-ships" effect.

The high level of financial dollarization appears to have been a key factor behind the ambivalence of investor confidence in the currency board and the easy shifts in market sentiment. On the one hand, by raising the stakes and creating incentives in favor of policies that would not undermine convertibility, in tranquil times dollarization seems to have reinforced the perception that convertibility would endure, which was reflected in a peso premium that, at its minimum, was remarkably low (Figure 2). On the other, during times of financial turbulence when the sustainability of the currency board was put to test, high dollarization exacerbated investor anxiety and the currency premium spiked sharply. By raising the costs of exit from the currency board to catastrophic levels, dollarization seems to have increased the scope for multiple equilibria and self-fulfilling runs, as manifested in a highly volatile currency premium.

\subsection{Bad times: a currency-growth-debt trap}

Right from the beginning of the De la Rúa administration (which assumed power in December 1999), the Argentine economy was caught in a CGD trap. The currency was overvalued, growth was faltering, and the debt was hard to service. This trap was in no small part due to major external shocks. This section analyzes the elements of the trap and the policy failures in addressing them.

The Argentine peso appreciated sharply relative to most trading partners, in tandem with the revaluation of the U.S. dollar vis-à-vis European and emerging market 
currencies (particularly the Brazilian real). ${ }^{17}$ The real exchange rate (RER) overvaluation, in turn, masked the precariousness of Argentina's sovereign debt position. To be sure, the reported debt-to-GDP ratio, while on the rise (from less than 40 percent in 1997 to over 50 percent by the end of 2000), was not high in comparison to other Latin American countries. However, when measured at the equilibrium RER, the debt-to-GDP ratio was very high and assailed by a potentially explosive dynamic. Perry and Servén (2002) estimate that, relative to a benchmark analysis of fiscal sustainability, the use of the equilibrium RER in the sustainability calculation adds 24 percentage points to the public sector debt-to-GDP ratio in 2001, and leads to an average increase of about two percentage points in the annual primary fiscal surplus required (in 2000-2003) to attain inter-temporal fiscal solvency.

After 1998, Argentina slipped into an unyielding economic recession and rising unemployment, ${ }^{18}$ triggered by a sudden stop in capital flows that, while regional in its origins, was particularly acute and persistent in Argentina after the 1999 Brazilian devaluation. ${ }^{19}$ This capital flow reversal, together with doubts about fiscal viability, was reflected in sharp increases in the marginal cost of capital for Argentina (as measured by the spread of Argentine bonds over U.S. Treasury bonds), reinforcing pessimistic expectations regarding future growth and fiscal revenues, and exacerbating the perception of a potentially explosive debt trajectory. All of this fed doubts about the sustainability of the one-peso-one-dollar commitment. ${ }^{20}$

The government's strategy to break free from the CGD trap focused on reviving growth, although the means to achieve this objective changed dramatically after April 2001, when Mr. Cavallo took the post of Minister of Economy. ${ }^{21}$ During 2000, growth resumption was sought indirectly-trying to regain investor confidence through fiscal adjustment, including the tax increase ("impuestazo") enacted in January 2000. It was hoped that improved confidence would eventually lead to more capital inflows and growth, making the debt and current account sustainable. To be sure, the authorities also tried to address the problem of currency overvaluation indirectly, through a rather

\footnotetext{
${ }^{17}$ Perry and Servén (2002), for example, estimate that, by the year 2000, the Argentine RER was overvalued by about 50 percent. While estimates may diverge, the perception of overvaluation was widespread both at home and abroad.

${ }^{18}$ GDP shrank by nearly 4 percent in 1999 (although it registered a rather strong, albeit fleeting, revival in the last quarter of 1999). GDP continued to contract at about 2 percent per year in 2000-2001. Open unemployment rose from about 13 percent in 1998 to over 15 percent in 2000.

${ }^{19}$ Perry and Servén (2002) provide evidence that: (i) during 1999 Argentina was not affected as severely as other countries in Latin America by the slowdown in capital flows; and (ii) the sharp reversal of capital flows to Argentina in 2000-2001 was mainly endogenous to domestic factors.

${ }^{20}$ Some people still argue that the currency was not overvalued, as most observers claimed at the time. Note, however, that, even if this was the case, a widespread belief that the currency is overvalued is enough to generate a preventive retrenchment of capital flows that could give rise to a CGD trap, as described in this section. See Razin and Sadka (2001) for an analytical discussion.

${ }^{21}$ See Appendix Table 2 for a chronology of the political and economic events.
} 
marginal flexibilization of labor markets. ${ }^{22}$ In addition, as confidence was not restored and growth failed to pick up, the authorities shifted their attention towards calming fears of a possible debt default. The December 2000 IMF bailout package (advertised as a US $\$ 40$ billion package) was negotiated with this latter objective prominently in mind. However, none of these actions achieved the expected results and hopes of reviving growth faded away.

Minister Cavallo banked on his prestige to pull off the rescue. Empowered by Congress with special powers, he focused on rekindling growth, but this time directly, through heterodox measures. These included imposing a tax on imports and subsidizing exports (a fiscal devaluation for trade transactions), lowering reserve requirements, and announcing the eventual peg of the peso to the dollar and the euro (with equal weights), once these two currencies reached parity. From hindsight, it is clear that the growthfocused strategy, particularly in Mr. Cavallo's heterodox version, was half-blind. It not only did not yield growth, it also escalated the uncertainty about the debt and currency components of CGD trap. ${ }^{23}$

Doubts about the maintenance of the one-to-one correspondence of the peso to the dollar soared after April 2001 (Figure 2). ${ }^{24}$ This correspondence had already been broken through the back door for trade transactions and it was feared that it could be broken also for financial transactions. In addition, Mr. Cavallo had pushed successfully for the resignation of central bank president Pedro Pou, who was viewed by investors as a strict guardian of monetary and banking system soundness. ${ }^{25}$ Moreover, Mr. Cavallo used his special powers to reform the central bank charter, removing limits on the ability of the central bank to inject liquidity, thereby effectively dismantling the money-issuance rule that underpinned convertibility. ${ }^{26}$

\footnotetext{
${ }^{22}$ The approval of the labor market reform was linked to a bribery scandal, in which senators were accused of receiving payments from the government to approve the law. The scandal was unresolved, leading to the resignation of vice president Carlos Alvarez.

${ }^{23}$ Whether this risky bet was justified ex-ante is difficult to ascertain given the foreseeable costs of attempting an early exit. At any rate, the decision illustrates how a government facing a dilemma between a sure loss and an improbable salvation is tempted to gamble by adopting desperate measures that make the loss even larger in the event those measures fail.

${ }^{24}$ For a detailed chronology of the impact of political and economic announcements on the currency premium, see Schmukler and Servén (2002).

${ }^{25}$ At the time of this writing (January 2003), the Argentine Supreme Court was discussing the constitutionality of Mr. Pou's forced resignation.

${ }^{26}$ As mentioned above, prior to the April 2001 amendments to the central bank charter, dollardenominated, internationally traded Argentine government bonds valued at market prices could be treated as part of the country's disposable international reserves. After the amendments, the claims on the government received by the central bank (in repo or as collateral) in the context of its liquidity operations with the banking system no longer counted as part of the maximum of 33 percent of disposable international reserves. Thus, the April 2001 amendments enabled unlimited injection of lender of last liquidity with the backing of government paper, thereby effectively eliminating the money issuance rule of convertibility. In practice, the claims on the government that the central bank received as part of its lender of last resort activity during 2001 did not exceed the 33 percent limit. Nevertheless, the amendment contributed to increasing the doubts that the currency board would be maintained.
} 
At the same time, uncertainty about the debt component of the CGD trap grew as the government procrastinated in taking a decision on the debt. Instead of accepting that an orderly approach to debt reduction was becoming a necessity following the failed attempts to restore growth, the government averted debt service arrears temporarily by absorbing the liquidity of the financial system-mainly of banks and pension funds. In particular, in April 2001, the government used moral suasion to place US\$2 billion of bonds with banks in Argentina, allowing banks to use those bonds to meet up to 18 percent of the liquidity requirement. The banking system thus became less liquid and more exposed to a government default. Total banking system claims on the government rose gradually from less than 10 percent of total bank assets at the end of 1994 to 15 percent at the end of 2000, and jumped to over 20 percent by end-2001, as shown in Figure 6. This, in turn, heightened concerns about a potential abandonment of the currency board. As choices to finance the deficit through debt rapidly shrank, the specter of money printing loomed bigger. In the process, the fate of public finances, the banking system, and the currency became tightly linked.

The elements of the CGD trap reinforced each other in a perverse way. Continued economic contraction, increasing doubts about the sustainability of the public debt, and soaring uncertainty about the permanence of the one-peso-one-dollar rule fell into a vicious circle. This led to capitulation-including a massive run on bank deposits (Figure 7). The run, in turn, precipitated an economic meltdown by the end of 2001, which featured the imposition of limits on cash withdrawals from bank accounts ("corralito") and the consequent disruption of the payment system. ${ }^{27}$

The "corralito" was immediately followed by angry riots that prompted changes in presidents, a default on the government debt, the abandonment of the currency board into floating (an initial 40 percent devaluation immediately proved insufficient), the forcible conversion of dollar-denominated financial contracts into peso-denominated ones with different conversion rates applied to bank loans and deposits ("asymmetric stock pesification"), and the lengthening of their maturities. ${ }^{28}$ This unprecedented destruction of property rights was compounded later on by new measures (e.g., the de-indexations of

\footnotetext{
${ }^{27}$ The name corralito ("little fence") was initially adopted because deposits could be used freely inside the financial system but could not leave the system. This measure should not be confused with the forcible reprogramming of time deposits that followed in January 2002, referred to locally as the corralón ("large fence").

${ }^{28}$ Dollar loans were forcibly converted to pesos at 1 dollar $=1$ peso, while bank deposits were converted at 1 dollar $=1.4$ pesos. Pesified loans and deposits were indexed to the CPI, although part of the loans were subsequently de-indexed. Also, pesified deposits (loans) were subject to a minimum (maximum), administratively imposed, interest rate. The asymmetric pesification transferred part of the currency mismatch that had previously resided in the balance sheets of debtors in the non-tradable sector to the balance sheets of their creditor banks, resulting in less losses than otherwise to depositors. However, the (already bankrupt) government undertook to compensate banks for the impact of the asymmetric pesification on their net worth, through the so-called "compensation bond." On impact, the asymmetric pesification left banks with a capital loss and a major open exposure to foreign exchange risk (because their foreign liabilities cannot be pesified through a domestic decree). The compensating bond would thus have to offset both problems. The amount of the compensating bond is estimated at 14.6 billion pesos. To close the open foreign exchange position, the equivalent of 13.8 billion pesos (US\$9.8 billion) of that total would have to be denominated in dollars.
} 
part of the pesified loans, changes in the corporate bankruptcy code, a series of court rulings on "amparos" regarding deposit freeze, etc.).

In the next section we abstract from the stream of ill-advised measures that followed the collapse of convertibility to examine in some detail the salient features of the depositor run that precipitated the collapse.

\subsection{Meltdown: currency and deposit run}

Understanding the nature of the bank run in Argentina is essential to answering key questions regarding alternative paths to exit convertibility. Could a different exit strategy have enabled the authorities to preserve, and capitalize on, the high quality of the banking system and its regulatory framework, including the large presence of foreign banks? Was the "corralito" a coarse measure mainly aimed at saving the few (mostly public) banks with significant fiscal exposures that were suffering large deposit withdrawals? If so, was the "corralito" a vehicle through which the government exported the crisis to otherwise liquid institutions, leading in the process to a currency run that made the abandonment of convertibility inevitable? Or was the "corralito" rather the consequence of a run on the banking system? What triggered the run, perceived currency risk, perceived country risk, or both? What was behind the run is ultimately an empirical question, to which we now turn.

To better identify the factors that fueled the run, we compiled a rich bank-level dataset on deposits that distinguishes both across currencies (peso and dollar), as well as deposit type (demand, savings, and time). We also use banks' balance sheet data to control for bank-specific fundamentals. We analyze the top 50 banks, which accounted for 98 percent of total private deposits as of December 2000. Our empirical analysis supports the view that it was the rising perception of currency risk that generated a run on the currency, illustrated by a shift from peso to dollar deposits between February 2001 and July-August 2001, which evolved into a run on bank deposits regardless of currency of denomination or bank characteristics, probably out of increasing fears that a major devaluation could lead to bank failures and some form of deposit confiscation. ${ }^{29}$

Figures 7 and 8 show the evolution of deposits and of the currency premium over time. Regarding demand and savings deposits, while dollar deposits remained stable, even increasing up to the end of 2001, peso deposits started to decline after February 2001. The pattern is more salient in the case of time deposits, with dollar deposits steadily increasing until the second semester of 2001.

The December 2000-November 2001 deposit withdrawal was not just focused on few banks or on certain types of banks (Figure 9). It spread to almost all banks as the crisis progressed. ${ }^{30}$ By November 2001, 47 of the top 50 banks had suffered withdrawals

\footnotetext{
${ }^{29}$ In this regard, the 2001 run presents a striking similarity with the post-Tequila crisis, both in terms of the displayed symptoms as well as the underlying drivers.

${ }^{30}$ Banks differed, however, in their level of liquidity. Towards the end of 2001, as the deposit run intensified, the government put pressure on the most liquid private banks to re-circulate their liquidity
} 
relative to December 2000. Local private, foreign private, and public banks were all affected by the run, with no particular ranking by type of bank. A breakdown by currency and deposit type confirms that there was no particular pattern regarding withdrawals by bank type (Figure 10). Withdrawals of peso deposits were generalized and substantial. The average withdrawal for the top 50 banks was 34 percent for peso demand and passbook savings deposits and about 40 percent for peso time deposits. But the figures are different for dollar deposits. There were more banks that gained rather than lost dollar demand and savings deposits-on average, the top 50 banks gained close to 25 percent of dollar demand and savings deposits relative to the December 2000 level. By contrast, more banks lost than gained dollar time deposits—on average, the top 50 banks lost 5 percent of their dollar time deposits, although 18 out of the 50 banks registered an increase in their dollar time deposits. This suggests that whatever flight to quality there may have been, it mainly involved dollar time deposits and did not favor, as expected, foreign-owned over locally owned banks.

A more formal examination of the deposit run yields the same insights. We follow the methodology used in Martinez Peria and Schmukler (2001), which regresses the change in monthly deposits on different bank-specific characteristics to gauge the importance of bank fundamentals. If depositors distinguished between banks with different risks, bank fundamentals would appear as statistically significant in the regression. We run the same regressions for different types of deposits and for different periods, namely, a "pre-crisis" period (1997-1999) and a "crisis" period (2000-2001). Bank fundamentals are chosen based on standard measures of bank risk characteristics. Since this information is published with a delay of three months, variables are lagged accordingly. We also add bank-type dummies to test whether the crisis affected different types of banks differently.

Table 4 reports the results for the monthly change in dollar and peso deposits, and for the pre-crisis and crisis periods. The ratio of capital to total assets and that of nonperforming to total loans are bank-specific risk features that had an statistically significant effect (with the expected sign) during the pre-crisis period. The other explanatory variables, including the bank-type dummies, are not significant. However, during the crisis period, almost all bank-specific risk variables become insignificant. Only cash over total assets is significant in the regression for peso deposits, while no variable is significant in the regression for dollar deposits. Table 5 shows that the proportion of the R-squared explained by bank fundamentals decreases from 19 percent during the pre-crisis period to less than 4 percent during the crisis period in the case of peso deposits. A similar phenomenon affects dollar deposits, with the proportion falling from 10 to 1 percent. In other words, the importance of systemic effects (relative to bank fundamentals) rose sharply during the crisis period, suggesting that whatever the influence bank-specific fundamentals had on depositors' behavior in the preceding

towards the relatively less liquid (mainly public) banks. This is consistent with the view of the corralito as an extreme (and highly inefficient) way of distributing the burden of the run between liquid and illiquid banks. It does not detract, however, from the fact that the run was systemic in nature and was not directed only to those banks with relatively weak fundamentals. 
period, it was dwarfed by systemic factors during the 2001 run, and confirming the pattern displayed in figures $7-10$ examined above. ${ }^{31}$

To further probe on the factors behind the systemic effects, we run regressions by type of deposits in which the time dummies are replaced by time-varying variables. The results are reported in Table 6 (bank fundamentals are included in the regressions but omitted from the table). The top panel of Table 6 displays the results for peso deposits, divided by demand and passbook savings deposits, on the one hand, and time deposits, on the other. The bottom panel shows similar estimations for dollar deposits. Regarding peso deposits, the currency risk (measured by the interest rate differential) is statistically significant for demand and savings as well as time deposits. This result is robust-it holds even when including country risk and the interaction between country risk and exposure to the public sector. ${ }^{32}$ By contrast, systemic variables are not statistically significant in the regression for dollar demand and passbook savings deposits-not too surprising given that these deposits remained flat throughout the crisis. Regarding dollar time deposits, the currency risk is statistically significant when introduced as the only systemic factor, but it becomes non-significant when country risk (measured by bond spreads) is introduced. Thus, while currency risk was the dominant factor behind the generalized withdrawal of peso deposits, country risk appears to be a more precise thermometer of the evolution of dollar time deposits. Overall, the result seems to support the view that the crisis was originated in a currency run that affected banks across the board, regardless of their fiscal exposure or other bank-specific characteristics.

\section{Living or dying with hard pegs: lessons from Argentina}

This section reviews the salient lessons that can be drawn from the Argentine experience for hard pegs and formally dollarized systems. Three sets of lessons are worth emphasizing. The first relates to the practical limitations of a hard peg (including its extreme version of formal dollarization), particularly in the case of countries that do not meet the conditions for an optimal dollar area. The second set relates to issues in designing appropriate prudential norms given the hard peg (that is, accepting its premise that the exchange rate will not be modified). The third one concerns an issue on which the literature on hard pegs has always been speculative: strategies to exit hard peg arrangements. While the Argentine case certainly does not provide a blueprint for a smooth exit, it does illustrate the costs of sub-optimal strategies.

\subsection{Limitations of hard pegs as commitment mechanisms}

As discussed in Section 2.1, one obvious benefit of a hard peg system is that, by providing savers with an unquestionable store of value, it boosts financial intermediation, albeit at the expense of rising financial dollarization. The drawbacks of hard pegs have been extensively discussed in the economic literature, particularly for the case of

\footnotetext{
${ }^{31}$ This pattern is similar to those obtained for the Tequila crisis in Argentina and Mexico, and the debt crisis in Chile, as studied by Martinez Peria and Schmukler (2001).

${ }^{32}$ The fact that the latter is never significant contradicts the view that depositors run from those banks most exposed to the public sector.
} 
countries, such as Argentina, that do not meet the conditions for an optimal currency area (see the beginning of Section 2). Nonetheless, advocates of hard pegs frequently downplay the practical difficulties of establishing greater nominal flexibility in fiscal spending and wages in light of the limitations imposed by the loss of the nominal exchange rate as an adjustment mechanism, and of establishing a fiscal discipline consistent with the loss of the inflation tax. ${ }^{33}$ Moreover, these advocates tend to overstate the potential disciplining spillovers of hard pegs. They often advertise hard pegs as an irrevocable decision that, inasmuch as it restricts monetary financing of the budget, can help foster fiscal prudence, inducing governments eventually to learn to adjust nominal fiscal spending. ${ }^{34}$

This view is naïve and ultimately wrong, particularly in the case of hard peg countries that are open to capital flows but far from meeting optimal currency area-type conditions, therefore exposed to significant shifts in the equilibrium RER. The fact is that no matter how credible, a currency board (or dollarization) per se does not create nominal flexibility and fiscal discipline. ${ }^{35}$ The Argentine experience illustrates this well. To start with, nominal flexibility in fiscal spending is seldom verified in practice (in either emerging or industrial economies). Political realities of democratic processes severely constrain the margin to reduce nominal fiscal expenditure, especially in the context of a recession. As noted, this was a decisive factor in the evolution of the Argentine CGD trap. Nominal adjustment of the Argentine budget was achieved only to a limited extent and in the context of a protracted recession. Indeed, the reduction in public expenditure that should have accompanied the curtailment of access to external financing did not go beyond an insufficient and politically costly wage cut never meant to be permanent. ${ }^{36}$

The restriction on monetary financing of the deficit was not relevant in practice during the good times of convertibility because Argentina had access to voluntary debt placements in international and local markets. In effect, the pro-cyclicality of access to international capital markets helped create incentives against appropriate fiscal discipline in good times. ${ }^{37}$ When foreign markets closed, the restriction imposed by convertibility was violated through a somewhat compulsory placing of domestic debt. And when even

33 To be sure, hard peg advocates recognize these needs, but tend to simply state them as obvious conditions for the success of hard pegs, without highlighting the practical obstacles to their feasibility. For instance, Calvo (2002) writes that hard pegs have "to be supplemented by adequate institutions and regulatory conditions. For example, it is essential that government wages and regulated prices show a high degree of flexibility."

${ }^{34}$ See, for example, Baliño and Enoch (1997) for a discussion of the pros and cons of currency boards.

${ }^{35}$ See, for example, Levy Yeyati (2001) or, for the case of Panamá, Goldfajn and Olivares (2001).

36 Public sector wages and contracts in the federal government were cut by 13 percent in the second semester of 2001, but the reduction could not be extended to provincial workers. Moreover, although the cuts were meant to adjust endogenously in order to meet the zero-deficit rule, further reductions were judged to be politically unfeasible and were never implemented.

37 Perry and Servén (2002) analyze cyclically adjusted measures of (federal government) fiscal stance. They show that fiscal policy thus assessed was unduly expansionary in the "good" years of 1996-1998, and that fiscal adjustment was actually insufficient during 1999-2001, except in few months leading to the 1999 election. 
compulsory access to local banks and other local sources of financing (like pension funds) was exhausted, the public sector resorted to the issuance of central government and provincial paper that differed from currency only cosmetically.

Figure 11 depicts this process. Growing financing needs were met in the first half of the 1990s by recourse to the sale of state-owned assets and, when this source dried up, by borrowing in international capital markets. After the Tequila crisis, the government started to rely on domestic savings, notably pension funds and local banks, which steadily increased their share up to 2001 . Once the funding capacity of the domestic markets was exhausted, the government resorted to the issuance of small-denomination federal bonds (lecop) redeemable for federal tax payments. ${ }^{38}$ Similarly, in the case of the province of Buenos Aires, financing needs exceeding local revenues and federal transfers were eventually met by the placement of provincial bonds in domestic markets and the launch of the province's own small denomination paper, the patacón (Table 7). ${ }^{39}$ Thus, the persistent fiscal imbalance, far from adjusting to the budget constraint presumably imposed by the monetary regime, de facto circumvented it, rendering the regime all but a formal arrangement in this regard.

Two lessons can be drawn from this evidence. Firstly, there are perils in trying to impose a hard budget constraint when the government is incapable of squaring its fiscal accounts in the short run. One key peril is the spillover of fiscal problems into the financial system. On its way towards outright monetary financing of its budget, the Argentine government dramatically increased the exposure of the banking sector to fiscal default. We discuss the prudential implications of this process in Section 3.2 below.

Secondly, the monetary discipline of hard pegs appears easier to abandon than often believed. This is illustrated by the relative ease with which the Argentine government in need of funds resorted to money printing with another name (lecops, patacones, and the like). It is also clear that the same could have happened under formal dollarization. Dollarization per se would not have overcome the CGD trap as long as the fiscal imbalance was a given (at least in the short term); it was not easily reversible by a reduction in nominal public expenditure. Dollarization too would have likely been accompanied by a proliferation of local quasi-monies that would have reflected the simple fact that a fiscal deficit cannot be eliminated merely by a monetary arrangement. Quasi-monies more than a problem in themselves are, therefore, a symptom of a deep inconsistency between a strict monetary framework and the nominal rigidities that this framework cannot magically eliminate.

\section{2. $\quad$ Prudential lessons}

\footnotetext{
38 The figure underestimates the monetary expansion, by excluding indirect deficit financing through central bank lending to Banco Nación, which accelerated substantially during 2001.

${ }^{39}$ Figure 11 understates the surge of quasi-money printing. As Table 7 indicates, a number of other provinces adopted similar mechanisms to finance their deficits and, as a result, the total stock of quasimonies reached more than 2.6 billion pesos or about 26 percent of total pesos in circulation by the end of December 2001, and had doubled by the end of March 2002.
} 
The financial system was not a cause of the Argentine crisis but rather its victim. The evidence clearly indicates that, under convertibility, Argentina was able to build a strong and well-supervised banking system-a model to be emulated by other emerging markets. Moreover, Argentine authorities displayed considerable innovative capacity in developing prudential norms, particularly in terms of liquidity buffers, suitable to a hard peg system (see Appendix Table 1).

Nonetheless, from hindsight, the Argentine experience reveals some prudential shortcomings and, hence, suggests directions in which prudential policy needs to be tailored further to better deal with risks that are specific not just to hard peg regimes but also, and more broadly, to financial systems that are de-facto highly dollarized. Three weaknesses in the otherwise sound Argentine regulatory framework can be identified by taking as given the rules of the convertibility game-i.e., by assuming the permanency of the one-peso-one-dollar rule. They have to do with: (i) the insufficient realization that general liquidity buffers do not fully protect the payments system from a run; (ii) the exposure of the banking system to government default; and (iii) the link between debtor capacity to pay and the deflationary adjustment to a more depreciated equilibrium RER.

High liquidity requirements, as those in effect in Argentina during the second half of the 1990s, enhance the resiliency of the banking system-they cushion the system visà-vis liquidity shocks and deter runs, thereby, reducing the scope for multiple equilibria. Thanks to its liquidity requirements, the Argentine banking system withstood a prolonged and severe process of deposit withdrawal in the Tequila and also during 2001. At the same time, however, the Argentine experience suggests that once a run is underway, relaxing liquid reserve requirements can have adverse signaling effects that exacerbate the attack on the peso (instead of spurring credit growth as Minister Cavallo hoped for), further weakening confidence. ${ }^{40}$ Moreover, Argentina illustrates that, as confidence collapses, a general liquidity requirement (available to all deposits on a first come first served basis) fails to protect the payment system, as liquidity is rapidly consumed by the flight of time deposits.

The lesson is sobering. In the absence of an effective and credible lender of last resort, the payment system is vulnerable and can collapse under a run, even when liquidity is high but still a fraction of deposits equally available to pay any deposit withdrawal. ${ }^{41}$ It thus would appear that, under a currency board or dollarization, the protection of the payment system from bank runs might actually require prudential norms that give some form of priority of claim over available liquidity to transactional deposits, that is, to deposits that are germane to the functioning of the payment system. This does

\footnotetext{
${ }^{40}$ During the Tequila crisis in the mid-1990s, the Argentine authorities reduced liquidity requirements to help the banking system confront the deposit withdrawals, and this regulatory action did not seem to have exacerbated such withdrawals. The deleterious effect of the relaxation of liquidity requirements during the 2001 run was probably because it contributed to the already high uncertainty about the authorities' commitment to the currency board. Many analysts cautioned about the potential negative effects of using prudential policy as a counter-cyclical instrument in 2001. In effect, this issue was a major cause of dispute between the central bank and the ministry of economy.

${ }^{41}$ See Chang and Velasco (2000) for an argument along these lines.
} 
not necessarily require a narrow-bank type structure. It could also be achieved, for instance, by an ex-ante rule that, under specified conditions, earmarks available liquidity to demand deposits. While the operationalization of this concept does not appear easy, the prudential principle on which it is based warrants serious consideration. The objective of such prudential innovation would be to preserve the functioning of the payment system even in the extreme scenario where banks are unable to honor withdrawals of time deposits. ${ }^{42}$

The second prudential weakness has to do with credit risk. It arises from the Argentine failure to sufficiently isolate the solvency of the banking system from the solvency of the government. As discussed earlier, no matter how credible, a currency board (or dollarization) per se does not create fiscal discipline. To the extent that banks hold significant claims on the domestic government, a fiscal and public debt crisis would immediately affect banking system solvency. However, one silver lining of convertibility (or dollarization) is that, in principle, it makes it possible to protect banking intermediation from the vagaries of the fiscal process, including an event of government debt default, as long as banks are not significantly exposed to domestic government risk. The reason is that the store of value that underpins financial intermediation in a currency board (or dollarized) country is ultimately the dollar, whose quality does not depend directly on the solvency of the domestic government. ${ }^{43}$ This feature should have been harnessed through prudential norms in Argentina, all the more considering the country's recurrent fiscal problems. As described in Appendix Table 1, the authorities moved in this direction belatedly, in 2000, when they introduced mark-to-market requirements for government bond holdings and established a positive weight for loans to the government for the purposes of determining regulatory capital requirements. It would have been advisable to take this approach more aggressively and much earlier in the decade, and to complement it by limiting the exposure to the public sector of individual banks, and the amount of government debt that could count as part of the assets eligible to meet bank liquidity requirements.

The third weakness has to do, again, with credit risk - the latent non-performing loans (NPLs) in the context of a misalignment of the RER relative to a more depreciated equilibrium level. Convertibility (or formal dollarization), as Roubini (2001) has correctly stressed, does not immunize a country from the balance sheet effects of a RER adjustment. In particular, RER overvaluation is corrected under convertibility (or dollarization) slowly, through painful deflation and unemployment (particularly if rigidities in the labor market are significant), which certainly erodes the capacity to pay

\footnotetext{
${ }^{42}$ Developments during the recent crisis in financially dollarized Uruguay are an ex-post rendition of this concept. In effect, as the run intensified, the Uruguayan authorities decided to concentrate central bank reserves (which were bolstered by an IMF-led emergency package) on fully backing demand deposits in troubled banks. Time deposits of troubled banks were, by contrast, restructured by decree. The same could be achieved in a more orderly manner by imposing ex-ante a stop-loss clause on the use of bank liquid reserves, forcing automatic restructuring of time deposits once the decline reaches certain threshold.

${ }^{43}$ In contrast, this condition cannot be obtained where the store of value is the domestic currency.
} 
of debtors whose earnings come from the non-tradable sector. ${ }^{44}$ Under a hard peg or a $d e$ facto highly dollarized financial system that breeds a systematic and severe "fear of floating," the erosion of capacity to pay of debtors in the non-tradable sector occurs regardless of whether the loans in question are denominated in dollars or in pesos.

The lesson here has much less to do with the Argentine failure to single out the currency of loan denomination in the design of its prudential norms, than with the failure to explicitly recognize the special credit risk of loans to debtors in the non-tradable sector-a credit risk that would materialize in the event of significant adverse shocks that led to a deflationary adjustment of the RER. This risk arises from the simple fact that debtors in the non-tradable sector cannot denominate their debts in terms of non-tradables or hedge when contracting debts in terms of tradables. The implication is that the authorities in fixed exchange rate economies would be well advised to establish relatively tougher loan classification criteria, higher loan-loss provisioning rules, and possibly also a higher weight for the purposes of measuring capital requirements for loans to the nontradable sector in either currency. ${ }^{45}$ In addition, the authorities could promote the development of a market for financial contracts indexed to the price of non-tradables.

A final point is useful to clarify how the previous analysis can be extended once the assumption of a permanent peg is relaxed. While the first two lessons are fairly general to any monetary arrangement, a distinction must be made in the third lesson for the case of financially dollarized economies in which changes in the nominal exchange rate have non-zero probability. While the currency of denomination is irrelevant where the peg is preserved, it is crucial in the event of a nominal depreciation of the local currency. In financially dollarized economies under flexible regimes, the considerations discussed in the previous paragraph apply only to dollar loans to non-tradable income producers. The presence of a not-fully-credible peg in a financially dollarized environment adds an obvious complication. Conditional on the survival of the peg, nontradable debtors are exposed to real exchange rate risk regardless of whether they borrow in pesos or in dollars. However, if the peg is abandoned, their exposure is more dramatic but only if they borrow in dollars. Thus, some degree of currency discrimination in prudential norms may be warranted in countries committed to a hard peg, although these

\footnotetext{
${ }^{44}$ Deflationary adjustment in a currency-board (or dollarized) country lowers the value of non-tradable income in terms of tradables, which implies that the burden of the debt rises (capacity to pay falls) for the non-tradable sector. By contrast, in a country with a flexible exchange rate (i.e., where a fixed parity is not part of the social contract) and without a substantial problem of dollar debts in the non-tradable sector, the adjustment to a more depreciated equilibrium RER would come through nominal depreciation, which would be associated with an improvement (via debt dilution) in the capacity to pay of debtors in the nontradable sector.

${ }^{45}$ Given that information asymmetry problems in buoyant times lead to rising bank exposure to the nontradable sector without adequate internalization of risks, a system of counter-cyclical loan-loss provisioning requirements, like the one established at end-1999 by the Bank of Spain (Circular No. 9/1999 of December 17, 1999), could help address risks in loans to the non-tradable sector. This is because lending booms are mainly to the non-tradable sector and, hence, the loan decay after the boom affects primarily loans to nontradable producers. The Spanish system requires a buildup of counter-cyclical provisions in good times (thereby curbing excessive dividend distributions), which are shifted into specific provisions in bad times (without passing through the income statement) as the loan portfolio decays.
} 
considerations should be weighted against a signaling effect that may weaken the credibility of the peg.

\subsection{Exit strategies}

With the benefit of hindsight, this section focuses on counterfactual analysis: What would have happened if Argentina had adopted different policies in the months before the crisis erupted? And, were there superior exit strategies open to Argentina from the CGD trap? By nature, this type of analysis is very difficult to back with real data and hard to substantiate. Nevertheless, a serious consideration of the different arguments presented here may help to draw relevant policy lessons for the future, particularly for countries with weak national currencies and highly dollarized financial systems.

Four alternative courses of action can be identified in relation to the Argentine case, particularly for the period after the January 1999 devaluation of the Brazilian real. Those that emphasized the RER overvaluation as the source of the sluggish growth recommended floating the currency, despite its adverse balance sheet effects (for instance, Roubini 2001, Krugman 2001). Those that disbelieved the existence of a demand for a floating peso recommended de jure dollarization (for instance, Dornbusch 2001, Calvo 2002). Those concerned about the balance sheet implications of a float but also worried about the RER overvaluation, recommended "stock pesification cum float"-i.e., the forcible conversion of dollar-denominated domestic contracts into CPIindexed peso-denominated ones, followed by the abandonment of the peg (in particular, Hausmann 2001). In Section 3.3 .4 below, we submit a fourth alternative: early dollarization of existing financial contracts ("stock dollarization") complemented by the introduction of a new national currency ("pesification at the margin") to function as a means of payments.

The main messages from the counterfactual analysis are as follows. The floating alternative could have corrected the overvaluation problem, but would have destroyed the convertibility contract and, by fueling the currency run of peso depositors, would have had a massive and immediate adverse impact on debtor and banking system solvency. Formal dollarization at a 1:1 rate would have respected the structure of property rights and would have had a better chance of preventing the run on deposits, but would have done nothing to attenuate the protracted and contractionary RER adjustment. ${ }^{46}$ Stock pesification cum float was probably the most disorderly exit alternative. While in principle it limited the immediate impact on balance sheets of the unavoidable RER adjustment by shifting the losses to depositors, its destructive effect on property rights and institutions will probably have long-lasting costs in terms of financial desintermediation. Moreover, by creating a huge peso overhang in the context of a currency run, it fueled the deposit flight and the unprecedented exchange rate overshooting that followed. For the same reasons, stock dollarization cum pesification at the margin could have averted the run. It would not have spared debtors in the nontradable sector from the adverse balance sheet effects of the devaluation. But, by

\footnotetext{
${ }^{46}$ If done at a much more depreciated rate, formal dollarization would have had similar (immediate) adverse effects on debtor and banking system solvency as the previous alternative.
} 
providing a margin for nominal flexibility, it could have facilitated the RER adjustment without unduly disfiguring property rights.

\subsubsection{Float}

Floating the peso would have immediately addressed the $\mathrm{C}$ component of the CGD trap, albeit at the cost of: (i) a run on the currency, as peso depositors moved to protect the real value of their savings, adding to the exchange rate overshooting; (ii) a sharp and immediate deterioration of the payment capacity of private and public sector debtors in the non-tradable sector, compounded by the overshooting to be expected from the currency run; and (iii) a run on bank deposits, as agents anticipated that banks would become insolvent immediately after the float. Moreover, a disorderly float in the context of widespread dollar debts among non-dollar earners would have likely led to a long period of continued RER depreciation, as Ecuador's experience suggests. ${ }^{47}$

While the second cost was inevitable in the context of a RER adjustment, and may have prompted government action to compensate bank losses and minimize depositors' misgivings about bank solvency, the currency run induced by the floating of the peso was the main drawback of the "just float" exit strategy. The resulting exchange rate overshooting would have not only accelerated the RER adjustment but also exacerbated its balance sheet effects. Even if depositors were allowed to dollarize their savings within the banking system (as Minister Cavallo encouraged by end-2001, once the run was underway), existing limits on foreign exchange open positions would have forced banks to drastically reduce dollar vis-à-vis peso deposit rates to balance their positions, which could have resulted in a dollar deposit flight. At any rate, it is not obvious whether an early move to a float would have triggered a run to the dollar bill. But it seems realistic to assume that, once underway, such a run would have only ended once deposits became dollarized, an outcome that could have been achieved in a more orderly fashion through a preemptive de jure dollarization of all financial contracts, as explained in Section 3.3.4.

From a political economy perspective, a substantive devaluation would have coordinated the actions of debtors (even those in the tradable sector that preserved their to capacity pay) and would have likely triggered an enormous pressure to the government to provide exchange rate insurance or some kind of compensation to private debtors, increasing either the fiscal cost of the bailout, the level of non-performing loans (NPLs), or both. ${ }^{48}$

Such likely consequences made the "just float" alternative highly unlikely politically, particularly in 1999 when there was not still a clear perception of the

\footnotetext{
${ }^{47}$ Ecuador's 1999 crisis illustrates the dire consequences of floating in the context of a weak fiscal position and widespread currency mismatches (dollar debts of non-dollar earners). The crisis deepened dramatically as nominal devaluation and debtor insolvency were caught in a feedback loop, leading to an excruciatingly long period of a collapsing real exchange rate. See De la Torre, García-Saltos, and Mascaró (2002).

${ }^{48}$ In turn, the perception of a bankrupt financial sector as NPLs mounted, could have re-ignited the run on bank deposits.
} 
imminence and size of the crisis. From a practical point of view, however, and as the margin to avoid a full-blown crisis narrowed, many analysts came to believe that, in the event of a float, something drastic had to be done to avoid its deleterious impact on balance sheets.

\subsubsection{Stock pesification cum float}

Because of widespread balance sheet mismatches (dollar debts of non-dollar earners), an increasing number of analysts believed that exiting convertibility by floating required the prior pesification of existing domestic financial contracts by decree. As the argument goes, without prior stock pesification, a significant and discrete devaluation would have immediately wrecked debtors in the non-tradable sector and, hence, the banking system. A way to deal with the adverse real and financial impact of a devaluation would have been a massive public bailout (of banks and firms), but this possibility was by mid-2001 out of the question for a government on the verge of default. By contrast, stock pesification cum float promised a way to address the $\mathrm{C}$ component of the CGD trap that presumably avoided the adverse balance sheet effect on debtors by transferring the burden of the expected bailout directly to private creditors. ${ }^{49}$ It was the alternative chosen by the Argentine government under pressure at the beginning of 2002 .

The forcible pesification of domestic financial contracts only created a mass of previously dollarized savings whose owners could not wait to re-dollarize them before the expected RER adjustment drastically reduced their dollar value. Even after abstracting from the social discontent that such a massive confiscation unsurprisingly stirred, ${ }^{50}$ one could not ignore the fact that pesification could only exacerbate the ongoing currency run, fueling the overshooting of the nominal exchange rate, and turning a potential solvency problem into an immediate liquidity problem. Stock pesification was a desperate attempt to escape what Eichengreen and Hausmann (1999) call the "original sin," but it gave way to a graver sin-the murder of money as store of value. ${ }^{51}$ Pesified Argentina now awaits a sort of miracle, that is, the resurrection of the peso as a store of value and, with it, the regeneration of peso financial intermediation.

\footnotetext{
49 Not surprisingly, this option appeared late in the crisis process and was originally presented in the context of the debt restructuring debate, with an emphasis on the compulsory conversion of sovereign debt. At the time of this writing, the Supreme Court was considering a ruling stipulating the re-dollarization of deposits. Since the re-dollarization of debts appeared politically unlikely, it was widely believed that such an action by the Supreme Court would induce the government to assume the banks' balance sheet losses. Under that scenario, the pesification adventure would go full circle to become a blanket exchange rate guarantee to be financed by taxpayers in years to come-a massive bailout that stock pesification was intended to avoid.

50 This discontent had non-negligible political economy consequences, as witnessed by the subsequent reluctance of the judicial system to validate the pesification and the decision of the government to allow the re-dollarization of reprogrammed deposits through their swap for dollar government bonds.

51 As defined by Eichengreen and Hausmann (1999) the "original sin" refers to the condition of a country that is unable to issue peso debt in international markets. As a result, such country is tragically trapped between currency mismatches (it can only issue long-term debt in dollars) and maturity mismatches (local markets only accept short-duration peso debt).
} 
Was stock pesification cum float a feasible alternative for earlier, more tranquil times? Would it have been less destructive then? We have serious doubts that there is a yes answer to these questions. Since forcible stock pesification cum float necessarily implied a departure from the one-peso-one-dollar rule, no government had an incentive to implement such a departure in tranquil times. Forcible pesification cum float was therefore a feasible alternative only for turbulent times. ${ }^{52}$ In addition, the massive violation of property rights implied in stock pesification (and the massive transfer of wealth involved) meant that any anticipation of it would have triggered a run. Hence, stock pesification cum float would have required the simultaneous establishment of a deposit freeze or securitization as well as widespread capital controls in order to keep depositors and investors from fleeing.

In sum, stock pesification cum float was arguably: (i) not an alternative that could have been feasibly implemented in tranquil times or without a change of government; (ii) an alternative that would have in any case provoked a run, requiring a deposit freeze of some form; and (iii) a deleterious alternative for financial intermediation. All these reasons lead us to believe that stock pesification was the least desirable alternative.

\subsubsection{Formal dollarization}

Was formal dollarization then a better option? Dollarization would have been consistent with the Argentine social contract based on the long-term commitment to onepeso-one-dollar, with salutary implications for depositor confidence, which would have been boosted not just because the perceived risk of deposit confiscation would have been dimmed significantly, but also because the option-value of foreign bank access to their parent's capital and liquidity would have been better protected. That is, even if a run would have occurred, foreign banks would have likely been more willing to stand behind their Argentine affiliates, compared to the current situation marked by confiscatory (and asymmetric) stock pesification.

Dollarization, though clearly not easy politically, would have not necessarily entailed a change of government-it would have arguably been within the scope of the government in power, inasmuch as it respected the one-peso-one-dollar rule. In this sense, there is an asymmetry in the political economy of dollarization versus stock pesification. It is generally less costly politically for developing-country governments to maintain an exchange rate parity than to break it. This argument is a fortiori stronger in the case of Argentina, given the crucial relevance of the currency board to the operation of the financial system.

The dollarization alternative would have been more likely to avert a run if adopted early in the game-i.e., before 2001. It was in fact considered by the Argentine government in 1999-2000, but it lost ground afterwards partly due to political polarization: it was construed as a symbol of support for Mr. Menem. By contrast, against a background of continued recession and increasing RER overvaluation, the

\footnotetext{
${ }^{52}$ Indeed, it was an alternative that almost by necessity had to be implemented in the context of a change in government.
} 
proposal of stock pesification cum float gained ground..$^{53}$ The feasibility and potentially salutary effects on depositor confidence of dollarization clearly narrowed during 2001, but did not disappear. A run became more likely once the government raided the liquidity of the financial system and was clearly headed towards default in the context of no access to capital markets. ${ }^{54}$

Could formal dollarization have still averted the run if adopted belatedly in 2001 ? Any answer to this question is, of course, highly speculative. Nonetheless, we are inclined to answer with a cautious yes. This is in part because, while deposit withdrawals in 2001 were probably motivated by heterogeneous expectations, much of the depositor activity appears to have reflected fears of a nominal devaluation, as discussed in Section 2.3. The possibility of no run under dollarization, even in the face of a default in government debt, appears reasonable in light of Ecuador's experience (Figure 12). In Ecuador, the sole announcement of dollarization in January 2000 (formal dollarization was put into law only in March 2000) had an immediate positive impact on deposits even though the Ecuadorian government was in open default (the debt restructuring agreement was signed several months after the dollarization announcement), most banks were highly exposed to the government, and it was no secret that many of the large banks were completely insolvent. There is no obvious reason to believe that developments would have been different in Argentina, particularly considering that the Argentine banking system was unquestionably in a substantially better shape than Ecuador's. Moreover, to reinforce the stabilizing effects of dollarization on depositor behavior, Argentina could have taken additional positive steps to relax the link between banking system solvency and fiscal solvency. ${ }^{55}$

In all, it is difficult to escape the conclusion that, from the point of view of increasing the chances for averting a run, preserving healthy links between money and banking, and preventing a disorderly RER adjustment, the more obvious non-traumatic strategy would have implied the dollarization of financial contracts. Under this strategy, though painfully, the banking system could have absorbed over time the losses associated with rising NPLs as the RER adjusted towards equilibrium through deflation. ${ }^{56}$

A formal move to full dollarization (of financial contracts and money in circulation), however, would have been clearly inadequate to mitigate the fundamental inconsistency between the peg to the dollar and Argentina's trade and productive

\footnotetext{
${ }^{53}$ It in fact became somewhat popular in academic and policy circles after Prof. Hausmann's public recommendation to Argentina, presented in the October 2001 Latin American and the Caribbean Economic Association Meetings in Montevideo (see Hausmann 2001). This proposal failed to anticipate that it would inevitably lead to a deposit freeze. The proposal, moreover, seriously underestimated the difficulty of establishing the peso as a store of value in order to re-generate financial intermediation going forward.

${ }^{54}$ The failure to secure debt rollover in July 2001 was probably the threshold.

${ }^{55}$ The decree passed in 2001 (Presidential Decree 1005) to enable the use of the amounts falling due in the government debt to pay taxes would have helped in this regard.

${ }^{56}$ Moreover, as the recent Uruguayan experience illustrates, a securitization of liabilities can be designed selectively (distinguishing across banks and, within them, between deposit and non-deposit claims), without changing the original currency of denomination of bank assets and liabilities.
} 
structure. And it would have not addressed the problem posed by severe practical limits to nominal flexibility in fiscal spending in a recessionary context. Initially, the main function of dollarization would have been to stabilize the financial system and hopefully stem the run. Over time, however, the premium of introducing some nominal flexibility would have risen. As a result, dollarization would have appeared as only one step towards building a viable paradigm that combines the dollar as the store of value with substantive nominal flexibility (particularly in wages and fiscal spending). ${ }^{57}$

\subsubsection{Stock dollarization cum pesification at the margin}

From the previous discussion it follows that dollarization was a better exit strategy only if it had been followed by greater nominal flexibility. Indeed, full dollarization would have eliminated two sources of flexibility available at the time: the pesodenomination of most prices and non-financial contracts, and the transactional demand for the local currency. In this section, we argue that the stabilizing benefits of stock dollarization could have been reaped while preserving these two source of flexibility through "pesification at the margin"-i.e., the introduction of a new domestic currency, initially circumscribed to transaction purposes, either by design or spontaneously, as was already occurring in Argentina, albeit in a disorderly manner, through the issuance of quasi-monies.

The simplest version of this alternative strategy would have implied dollarizing by decree the stock of existing financial contracts (without redeeming the pesos in circulation with dollars), in order to stem the run and stabilize financial conditions, and then consolidating into a single (new) national currency the peso and quasi-monies (such as the lecops and patacones) in circulation. That national currency would have floated against the dollar and would have been voluntarily used for future flows (payments, wage and prices, and new financial contracts). It would have had legal tender privileges under the control of the central bank. This process would have provided a much less disruptive way out of the rigid constraint imposed by the one-to-one rule, without unduly violating existing contracts. By offering the government an escape valve out of nominal fiscal rigidities in the face of a drying up in financing, the consolidation of the peso and quasimonies in circulation into a single currency would have turned the disorderly situation of quasi-monies into an opportunity for recomposing a degree of sustainable flexibility (to adjust the budget as well as real wages) in a financially dollarized economy.

In Argentina, not only did the recourse to printing quasi-monies relax the cash flow constraints faced by the public sector. It also worked as an adjustment mechanism for the private sector, which rapidly embraced the new "bills" as an instrument to reduce labor costs and, thus, circumvent labor market rigidities. However, most of these quasimonies were accepted for tax payments at face value. This, coupled with the convertibility of the peso in which they were denominated, limited the nominal flexibility

\footnotetext{
57 This paradigm corresponds to what we elsewhere call the "dollar trinity." A key element of such trinity is sound institutions, which we believe are a key precondition irrespective of the exchange rate arrangement in place. See De la Torre, Levy Yeyati, and Schmukler (2003).
} 
that could be achieved through its use to a secondary market discount that never exceeded 10 percent. $^{58}$

To be sure, the introduction of a new currency may find political support only once a crisis is well underway. Even at that stage, it is more likely that the process of pesification at the margin in a currency board or dollarized country would start with the spontaneous printing of quasi-monies. However, it seems plausible that, as part of crisis management and resolution, once a quasi-money has emerged spontaneously the authorities could shepherd it and eventually formalize it into a new currency. At any rate, while the precise manner in which pesification at the margin could have been instrumented is a valid matter for debate, the basic process is somewhat of a moot point, given that the emergence of local currencies has to be resolved eventually in some form. ${ }^{59}$

The logic of pesification at the margin, grounded theoretically and empirically in the distinction between currency and asset substitution discussed above, is reinforced by the post-devaluation experience in Argentina. The legal and political obstacles that hampered the government's strategy to stock pesify exemplify the difficulty of establishing the peso as a store of value. By contrast, the transactional demand for the domestic currency (both for the old peso and the quasi-monies) remained relatively stable even through the depths of the crisis, as the worst devaluation expectations materialized (Figure 13). ${ }^{60}$ This evidence suggests that stock dollarization cum pesification at the margin was a viable option for Argentina.

Arguably, reluctant acceptance of the new local currency could have fueled a sharp depreciation that would have defeated the objective of achieving a gradual and less traumatic RER adjustment, prompting central bank foreign exchange intervention and undesired nominal uncertainty. Ultimately, whether dollarization should have been extended, preemptively, to the purchase of pesos in circulation, or be limited to financial contracts only is also a matter for debate, with the answer depending on the estimated demand for the new local currency.

In any event, the new currency would have been, initially, part of a bi-monetary system in which the peso would have been used, as before, for transactions and as unit of denomination for most wages and prices, while the dollar would have retained its role as store of value for financial savings. The new currency would have realistically been externally non-convertible, fluctuating against the dollar. Moreover, in addition to its legal tender status, it could have possibly been granted exclusivity for tax payments purposes, so as to consolidate its transactional demand.

\footnotetext{
${ }^{58}$ The discount was due more to a liquidity premium than to perceived credit risk.

${ }^{59}$ We deliberately abstract from the problem of an unfair wealth transfer between different issuers once currencies are monetized by a central bank. Conceivably, such transfers could be undone either within the monetization scheme or directly through countervailing budgetary transfers.

${ }^{60}$ As noted above, the degree of dollarization of deposits in Argentina has historically been inversely related to their transactional nature (Figure 4). The flipside of this is the low level of dollarization of bank overdrafts (Figure 3 ).
} 
Pesification at the margin is certainly not a panacea, but it would have allowed a marginal degree of nominal flexibility for a dollarized financial system-flexibility to adjust fiscal spending to income and, to the extent that there was less than complete indexation of wages and prices to the dollar, to help correct misalignments in the RER. While the adverse balance sheet effects of RER adjustment on debtors in the non-tradable sector were inevitable, pesification at the margin would have mitigated the need for a long recessionary and deflationary adjustment of the RER, could have prevented the collapse of the banking sector, and would have avoided the long-lasting effects of the massive violation of the rule of law as a consequence of a forcible stock pesification. Ultimately, the sustainability of pesification at the margin would have crucially depended on the re-composition of strong and viable fiscal institutions, financial reforms designed to address the risks of dollar loans to the non-tradable sector, and the strengthening of the local currency through an independent monetary policy credibly focused on price stability.

\section{Final remarks}

Although now devastated by its crisis, the main challenge for Argentina currently is no different in nature from that faced at the beginning of the convertibility decade: to build a strong and sustainable link between money and financial intermediation, given the initial condition of a weak currency. ${ }^{61}$

Formulating the basic challenge in this way shifts the debate on bi-polar (floating versus hard peg) exchange rate systems to the terrain of financial intermediation and financial globalization. Once in this terrain, it is easy to see that a one-dimensional focus on the fix-float dilemma is insufficient. In effect, having a national currency that floats (freely or dirtily, it does not matter) and thus helps the RER to adjust to shocks is not enough if, at the same time, financial intermediation in that currency is non-existent or shallow and dominated by extremely short-duration contracts. Similarly, having a hard peg (including formal dollarization) and thus enjoying dollarized financial markets that are deeper and with longer-duration contracts could be extremely hazardous in the absence of adequate nominal flexibility.

In the heyday of the currency board, Argentina was able to develop a relatively deep and, by most standard measures, sound banking system, but its inability to generate a minimum degree of nominal flexibility to deal with shocks that resulted in a major depreciation of the equilibrium RER proved to be ultimately devastating. After the collapse of the currency board, Argentina regained a currency that floats and thus facilitates rapid adjustment in the RER. But financial intermediation has been all but wiped out. Argentina, which previously had financial intermediation without a flexible currency, now has flexibility without financial intermediation. Hence the central challenge for Argentina is how to re-construct sustainable links between money and

\footnotetext{
${ }^{61}$ De la Torre, Levy Yeyati, and Schmukler (2003) define "weak currency" as one not accepted as a reliable store of value by either residents or non-residents, a concept that relates to Eichengreen and Hausmann's (1999) "original sin" and to the widespread financial dollarization observed in numerous developing countries.
} 
financial intermediation. It is the same challenge that haunts many weak currency countries regardless of their ostensible exchange rate arrangements.

What is specific to Argentina is the daunting difficulty in tackling that challenge. During the 50 years that preceded convertibility, Argentine citizens were subject to a history of intermittent debasement of the national currency. Convertibility soothed those nightmares away with a heavy legal armor designed to make people believe that the ultimate store of value for their savings was the dollar-a hard currency that national mischief could not debase. Then the currency board imploded via the forcible pesification of financial contracts, which debased something even more fundamental than a national currency, namely, the contractual environment itself.

If major price instability is avoided, pesified Argentina should be able to maintain and enhance the function of the peso as a means of payment. That is the relatively easy part. As long as inflation is not out of control, the transactions demand for pesos is likely to be resiliently stable. The difficult part would of course be the establishment of the peso as a reliable store of value that can underpin sound financial intermediation. In effect, the re-establishment of the peso as a means of payment, even if sustained through a viable fiscal process, is not of itself an automatic guarantee that the peso would become a trusted receptacle for saving, particularly considering that the bad memory of the forcible pesification of their savings is likely to torment the Argentines for a long time.

If the goal in Argentina is to promote the peso as the currency for financial intermediation through limits or outright prohibition of dollar deposits and credit, then one might expect many years of a relatively narrow banking system (focused mainly on payments) while credible institutions are built and proven. Alternatively, a bi-monetary scheme (peso transactions and dollar savings) may be considered to try to restore a degree of financial intermediation earlier in the game, although the prospects for the restoration of dollar-based financial intermediation appear also bleak, given the severe damage to the contractual environment inflicted by stock pesification. ${ }^{62}$ In either case, there is no substitute to the hard work of institution building to underpin sustainable linkages between money and banking.

\footnotetext{
${ }^{62}$ The prudential lessons drawn from the Argentine case should come in handy to better internalize and manage the attendant risks if financial re-dollarization is the option of choice.
} 


\section{References}

Baliño, Tomás, and Charles Enoch, 1997, "Currency Board Arrangements Issues and Experiences," Occasional Paper No. 151, International Monetary Fund, August.

Broda, Cristian, and Eduardo Levy Yeyati, 2001, "Dollarization and the Lender of Last Resort," forthcoming in Dollarization, MIT Press.

Calomiris, Charles, and Andrew Powell, 2001, "The Argentine Financial System under the Currency Board," mimeo, Columbia University.

Calvo, Guillermo, 2002, "The Case for Hard Pegs," mimeo, University of Maryland.

Calvo, Guillermo, Alejandro Izquierdo, and Ernesto Talvi, 2002, "Sudden Stops, the Real Exchange Rate and Fiscal Sustainability: Argentina's Lessons," mimeo, InterAmerican Development Bank, paper presented at the Annual Meetings of the IADB.

Chang, Roberto, and Andrés Velasco, 2000, "Liquidity Crises in Emerging Markets: Theory and Policy," in NBER Macroeconomics Annual, Ben Bernanke and Julio Rotemberg (eds.), MIT Press, Cambridge.

De la Torre, Augusto, 2000, "Resolving Bank Failures in Argentina," Policy Research Working Paper 2295, March.

De la Torre, Augusto, Roberto García-Saltos, and Yira Mascaró, 2002, "Banking, Currency, and Debt Meltdown: Ecuador Crisis in the Late 1990s," in process.

De la Torre, Augusto, Eduardo Levy Yeyati, and Sergio Schmukler, 2003, "Financial Globalization: Unequal Blessings," forthcoming, International Finance.

Dornbusch, Rudiger, 2001, "Argentina at the End of the Rope ," mimeo, MIT.

Eichengreen, Barry, and Ricardo Hausmann, 1999, "Exchange Rates and Financial Fragility," NBER Working Paper No. 7418, November.

Feldstein, Martin, 2002, "Argentina's Fall: Lessons from the Latest Financial Crisis," Foreign Affairs, March/April.

Frankel, Jeffrey, Eduardo Fajnzylber, Sergio Schmukler, and Luis Servén, 2001, "Verifying Exchange Rate Regimes," Journal of Development Economics, 66:2, pp. 351-386.

Gavin, Michael, and Enrico Perotti, 1997, "Fiscal Policy in Latin America", in NBER Macroeconomics Annual, Ben Bernanke and Julio Rotemberg (eds.), MIT Press, Cambridge.

Goldfajn, Ilan, and Gino Olivares, 2001, "On Full Dollarization: The Case of Panama," Economia 1.2, Spring.

Hausmann, Ricardo, 2001, "A Way Out for Argentina: The Currency Board Cannot Survive Much Longer," Financial Times, October 30.

Hausmann, Ricardo, and Andrés Velasco, 2002, "Hard Money's Soft Underbelly: Understanding the Argentine Crisis," forthcoming, Brookings Trade Forum.

Ize, Alain, and Eduardo Levy Yeyati, 2002, "Financial Dollarization," forthcoming, Journal of International Economics.

Krugman, Paul, 2001, "Notes on Depreciation, the Yen, and the Argentino," New York Times, December 28, http://www.wws.princeton.edu/ pkrugman/argentino.html.

Levy Yeyati, Eduardo, 2001, "10 años de Convertibilidad: La Experiencia Argentina," Revista de Análisis Económico, 16:2. 
Martinez Peria, Maria Soledad, and Sergio Schmukler, 2001, "Do Depositors Punish Banks for "Bad" Behavior? Market Discipline, Deposit Insurance, and Banking Crises," Journal of Finance, 56:3, pp. 1029-1051.

Mussa, Michael, 2002, "Argentina and the Fund: From Triumph to Tragedy," mimeo, Institute for International Economics.

Perry, Guillermo, and Luis Servén, 2002, "The Anatomy and Physiology of a Multiple Crisis: Why Was Argentina Special and What Can We Learn from It?," mimeo, World Bank.

Powell, Andrew, 2002, “Argentina's Avoidable Crisis: Bad Luck, Bad Economics, Bad Politics, Bad Advice," forthcoming, Brookings Trade Forum.

Razin, Assaf, and Efraim Sadka, 2001, "Country Risk and Capital Flow Reversals," Economic Letters, 72:1, pp. 73-77.

Roubini, Nouriel, 2001, "Should Argentina Dollarize or Float? The Pros and Cons of Alternative Exchange Rate Regimes and Their Implications for Domestic and Foreign Debt Restructuring/Reduction," mimeo, New York University, December.

Schmukler, Sergio, and Luis Servén, 2002, "Pricing Currency Risk under Currency Boards," Journal of Development Economics, 69:2, pp. 367-391, December.

The Economist, 2002, “Argentina's Bottomless Pit," Economic Focus, Aug $8^{\text {th }}$.

Tornell, Aaron, and Andrés Velasco, 2000, "Fixed Versus Flexible Exchange Rates: Which Provides More Fiscal Discipline?" Journal of Monetary Economics, 45:2, pp. 399-436.

World Bank, 1998, Argentina: Financial Sector Review, Report No. 17864-AR, September.

World Bank, 1999, Argentina: Implementation Completion Report, Provincial Bank Privatization Loan and Bank Reform Loan, Report No. 19467, June. 


\section{Figure 1}

\section{Financial Deepening}

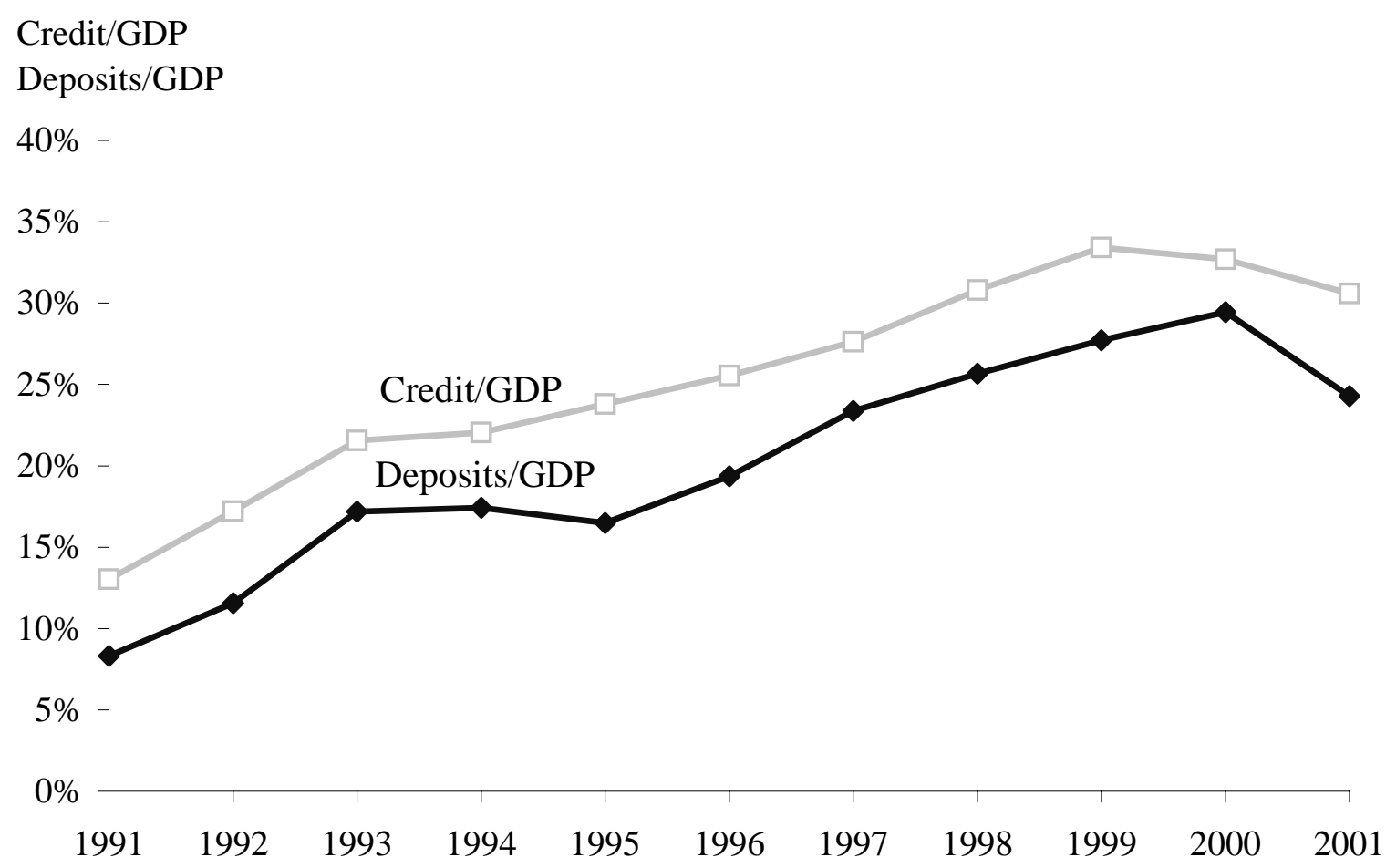

Credit includes loans to private sector, loans to public sector, loans to residents abroad, and private and public securities held by the financial system. Deposits include demand deposits, savings deposits, time deposits, and other deposits, by private sector, public sector, and residents abroad. Figures correspond to end-of-year values. Sources: Central Bank of Argentina and The World Bank 
Figure 2

\section{Loan Dollarization and Currency Premium}

Credit in U.S. Dollars

over Total Credit

Basis Points

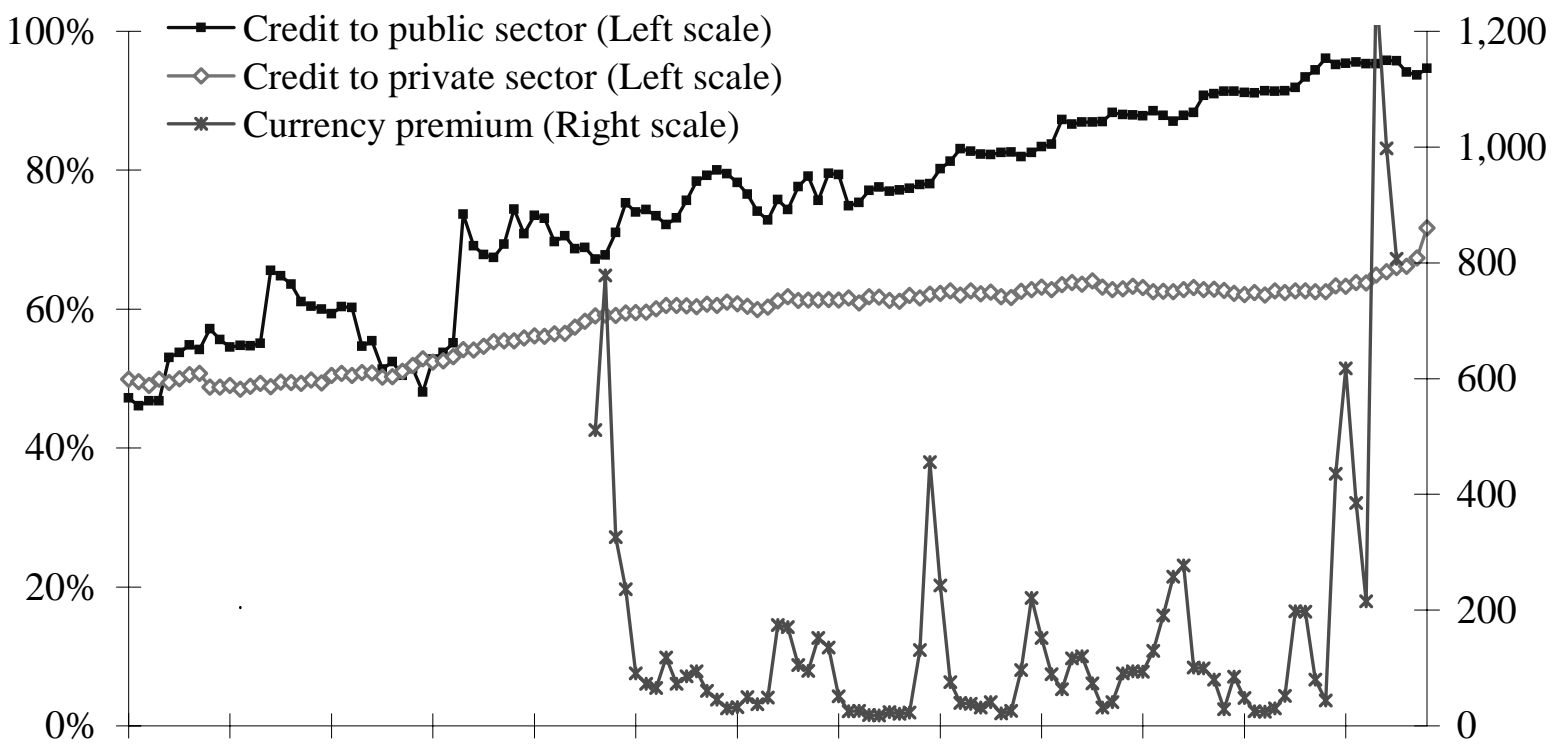

Apr- Feb- Dec- Oct- Aug- Jun- Apr- Feb- Dec- Oct- Aug- Jun- Apr$\begin{array}{lllllllllllll}91 & 92 & 92 & 93 & 94 & 95 & 96 & 97 & 97 & 98 & 99 & 00 & 01\end{array}$

The currency premium is measured by the differential between peso and dollar interbank deposit rates, using daily one-month interest rate premium. Credit to public and private sector correspond to end-of-period values and currency premium is monthly average.

Source: Central Bank of Argentina 
Figure 3

Private Sector Dollarization

By Type of Credit

Credit in U.S. Dollars

over Total Credit

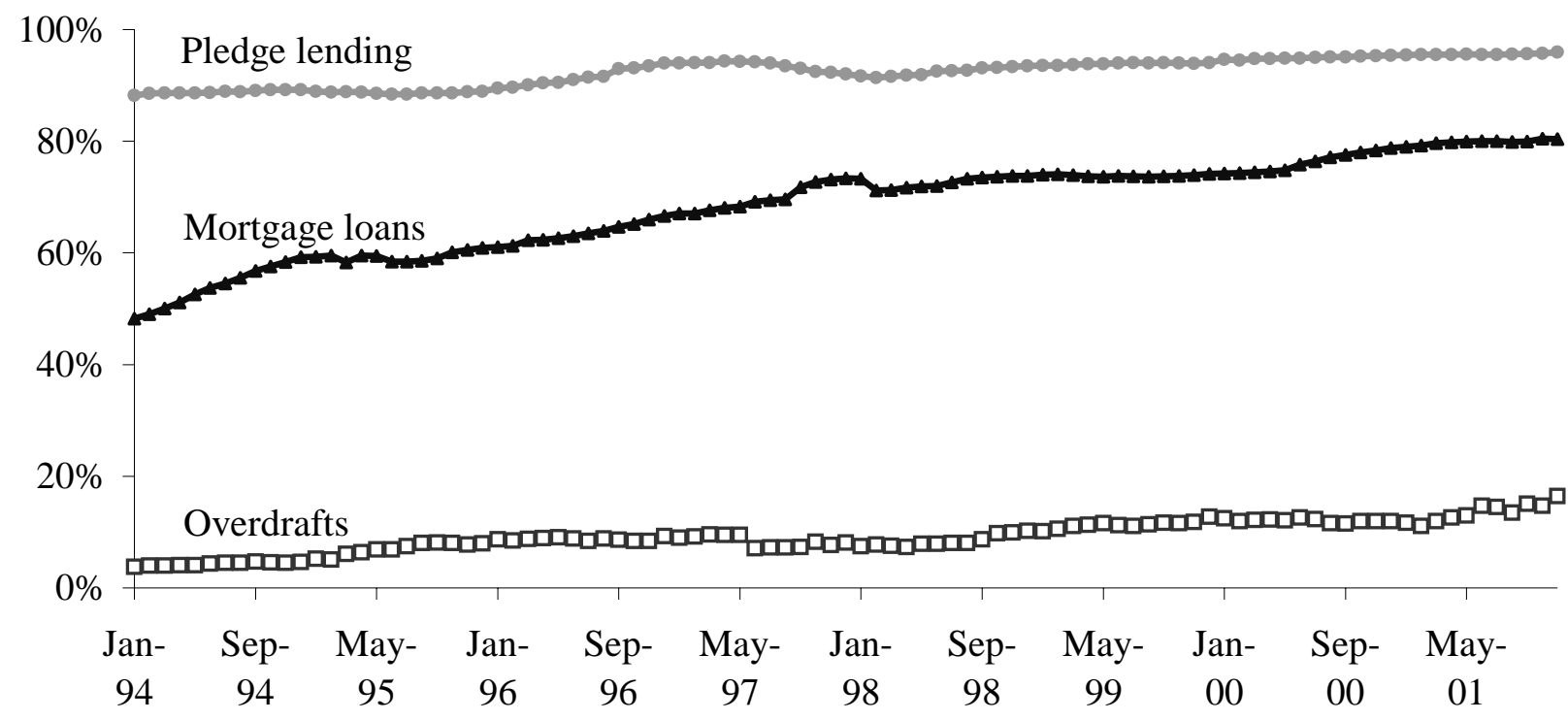

Firm's Balance Sheet Dollarization

Average Share of U.S.

Dollar Debt across Firms

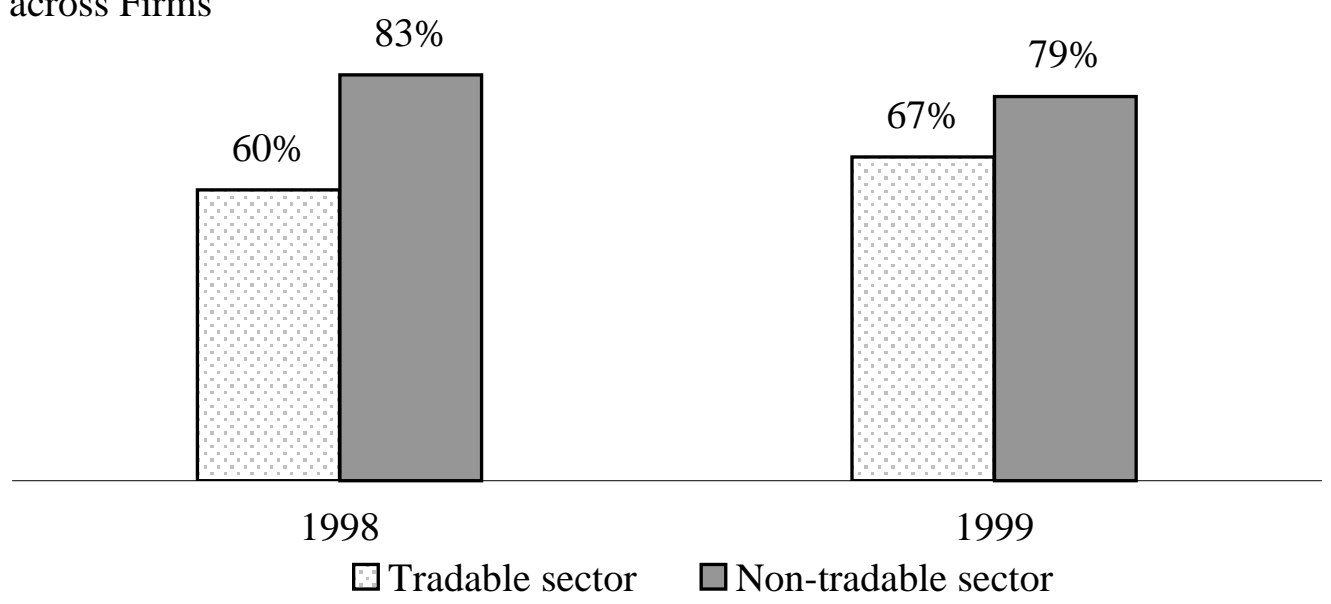

Sources: Central Bank of Argentina and Buenos Aires Stock Exchange 
Figure 4

Dollar Deposits over

\section{Dollarization by Type of Deposit}

Total Deposits

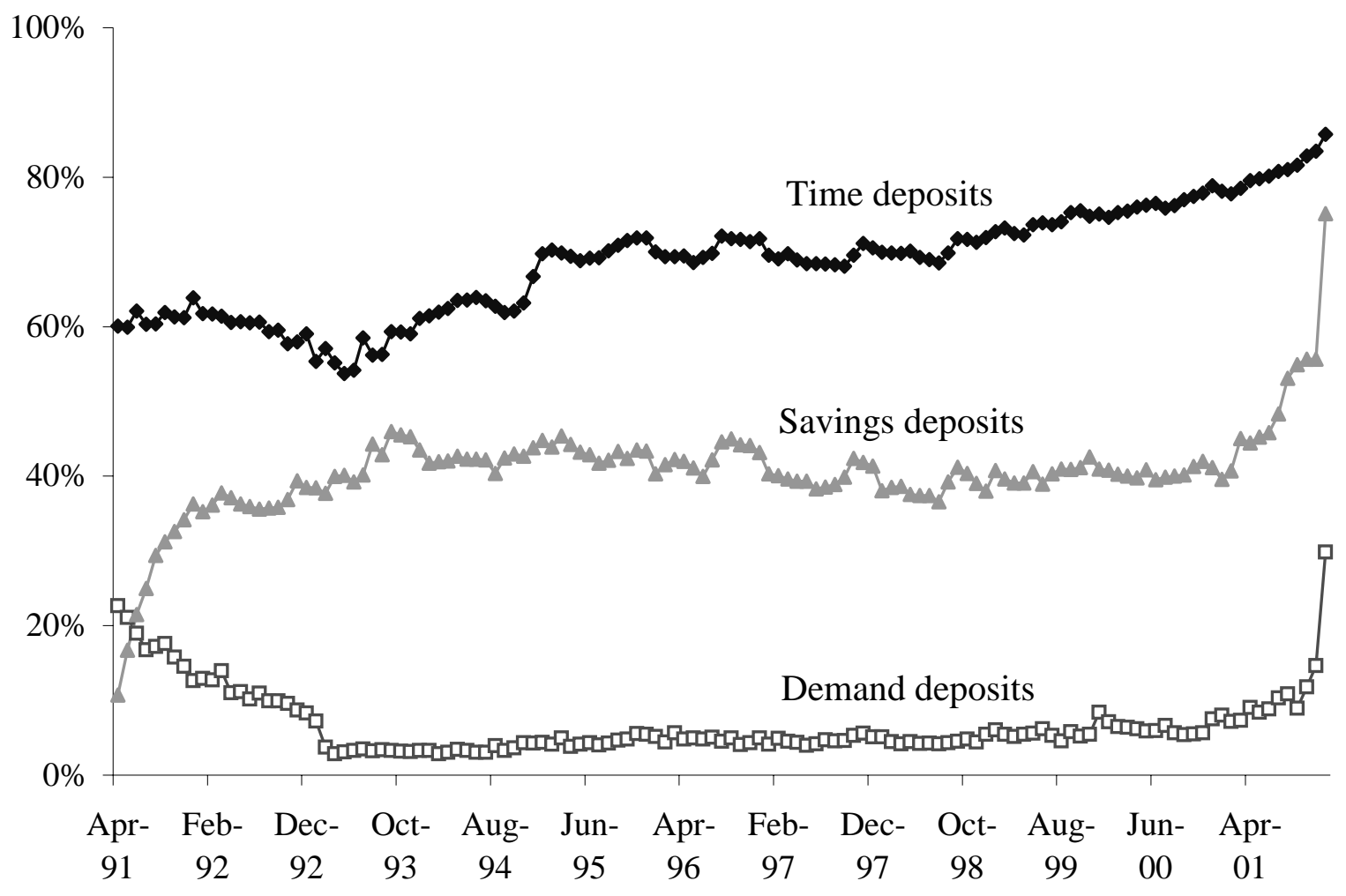

Source: Central Bank of Argentina 
Figure 5

Interest Rate and Risk Spreads by Type of Loan

Peso-Dollar Interest Rate Spread

Basis Points

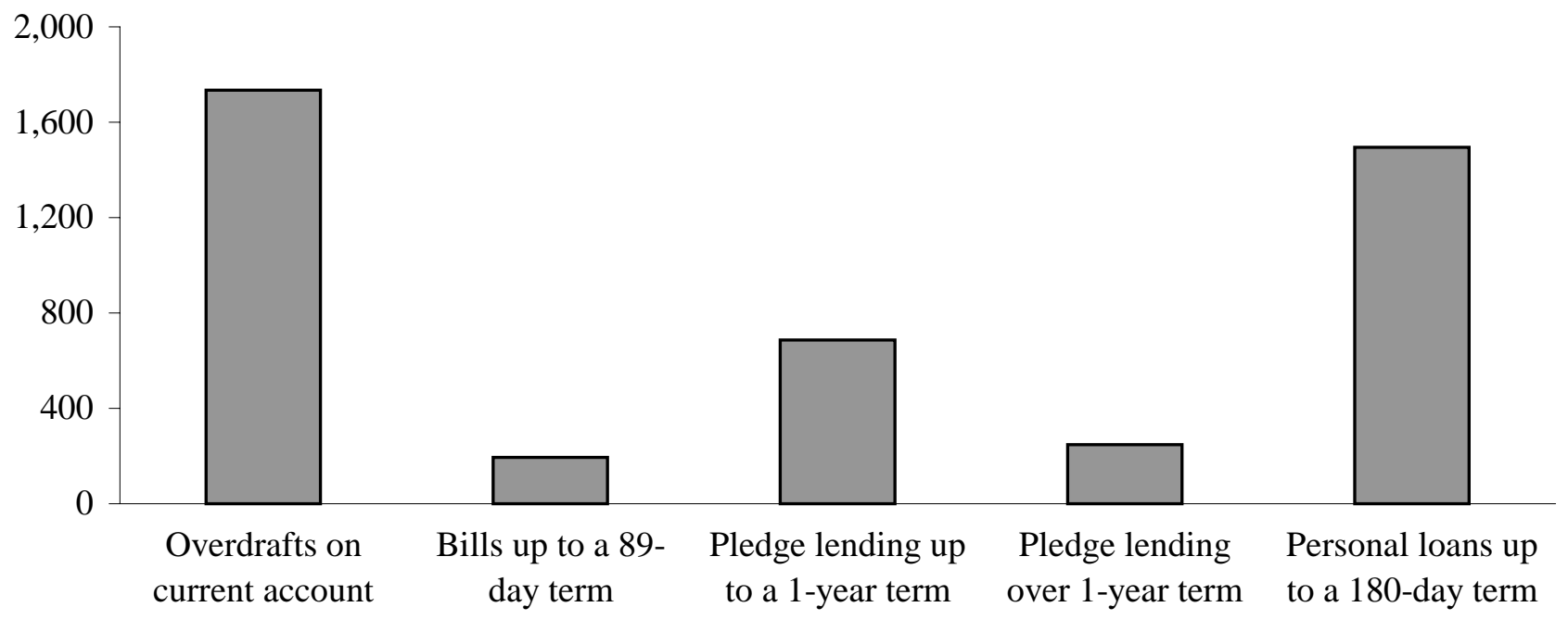

Risk Indicator Spread

Peso-Dollar Risk Spread

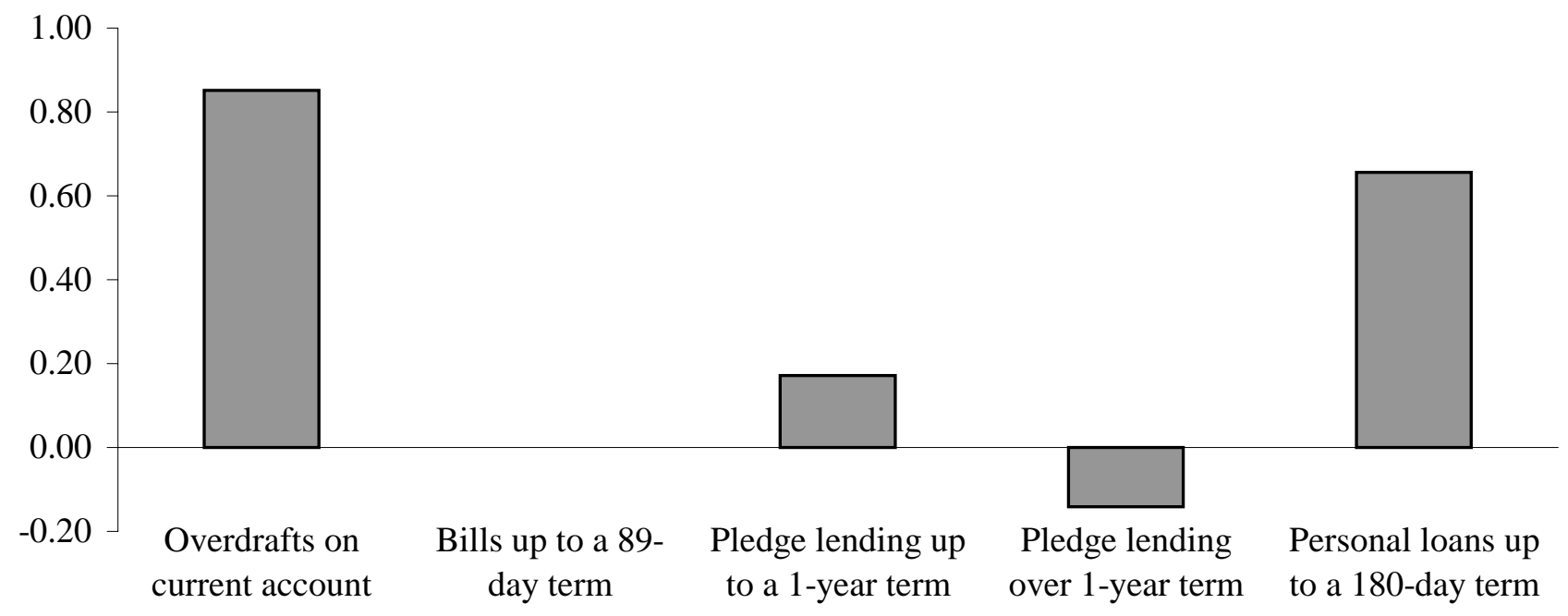

The top figure shows the average spread between peso and dollar financing interest rates. The bottom figure shows the average spread between peso and dollar financing risk indicators. The period covered is July 1993-December 1999, when the risk indicator was different for peso and dollar financing. Mortgage loans are excluded because only few banks in the system granted mortgage loans in pesos during this period. Note that the peso-dollar risk spread for bills up to a 89-day term is zero although the interest rate spread is positive. This is due to the fact that when the interest rate spread is small, the same risk indicator is used for peso and dollar loans.

Source: Central Bank of Argentina 
Figure 6

Financial System: Exposure to Public Sector

Total Assets

(Millions of Dollars)
164,100

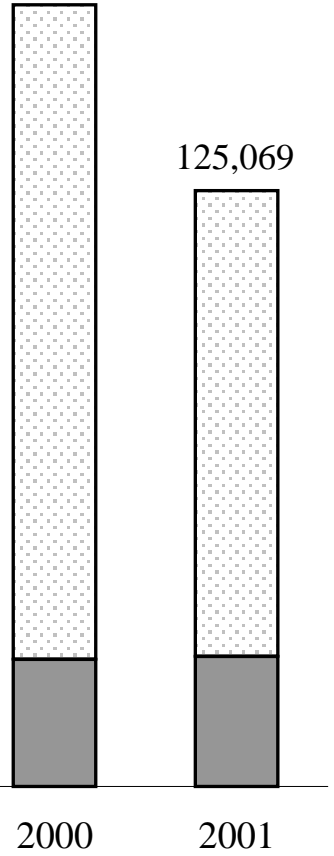

$\square$ Claims on the public sector

$\square$ Liquid assets and claims on the private sector

Share of Claims on the Public

Sector to Total Assets

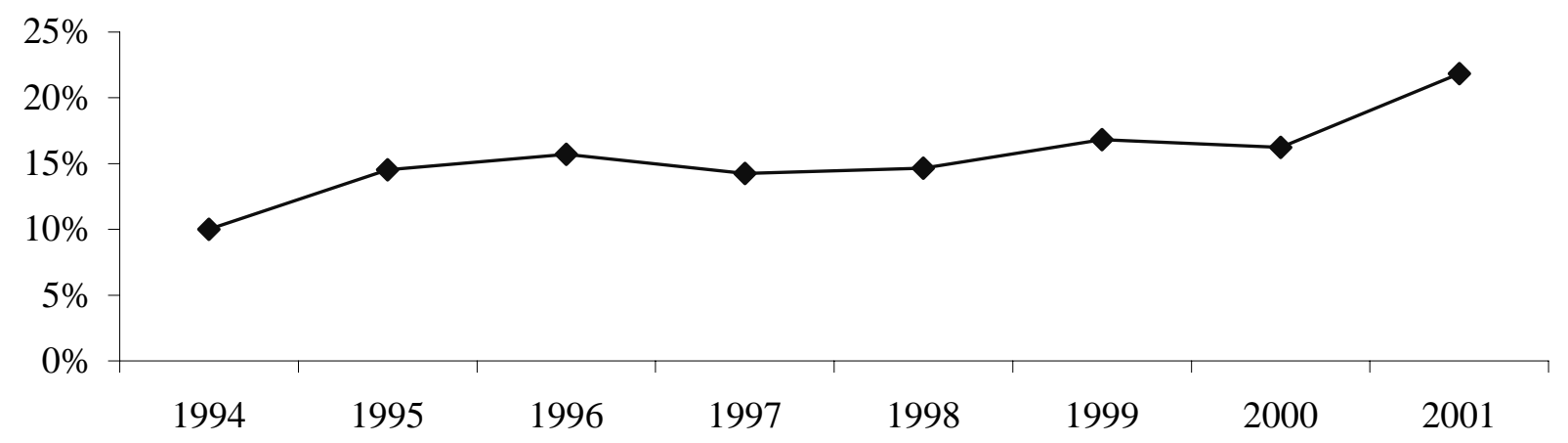

Financial system is defined to include public banks, private domestic banks, foreign banks, and non-bank financial institutions. Figures correspond to end-of-year values.

Source: Central Bank of Argentina 
Figure 7

\section{Evolution of Private Deposits}

Index of Deposits

(=100 in December 2000)

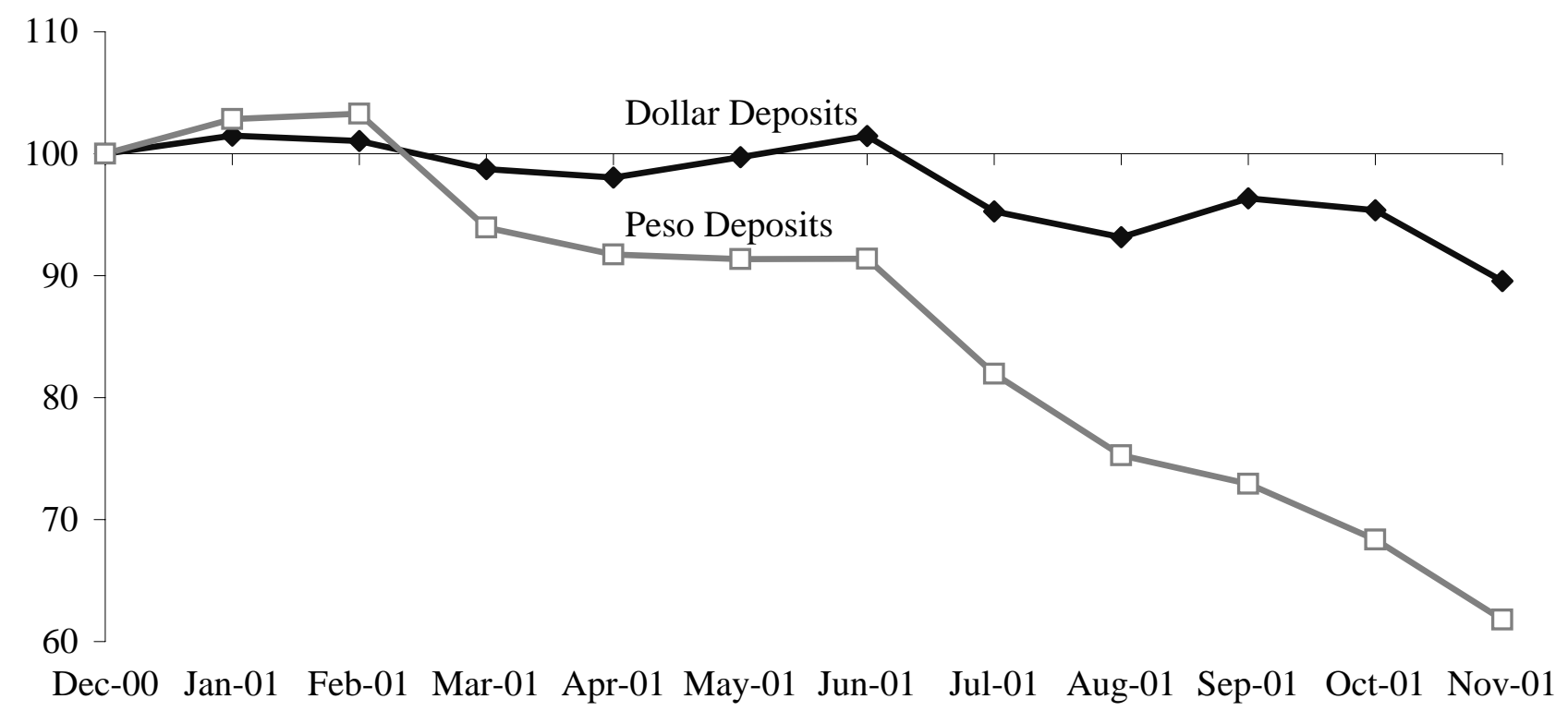

Source: Central Bank of Argentina 
Figure 8

Millions of Dollars

\section{Demand and Savings Deposits}

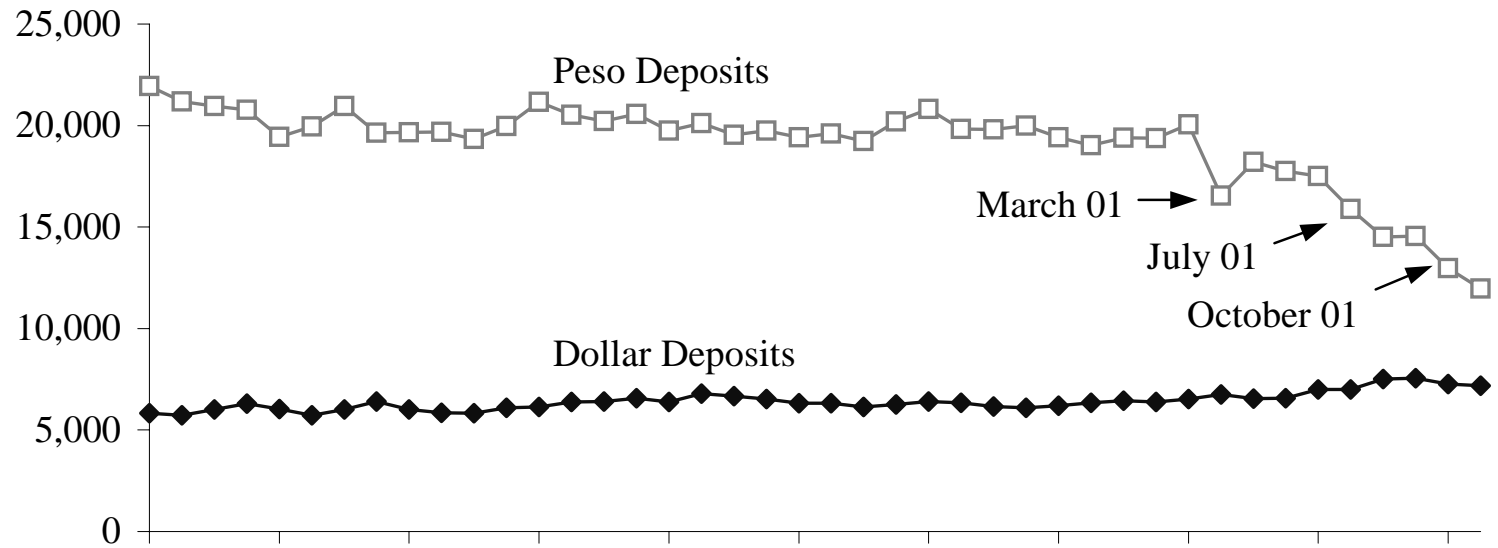

Jun-98 Oct-98 Feb-99 Jun-99 Oct-99 Feb-00 Jun-00 Oct-00 Feb-01 Jun-01 Oct-01

Millions of Dollars

Time Deposits

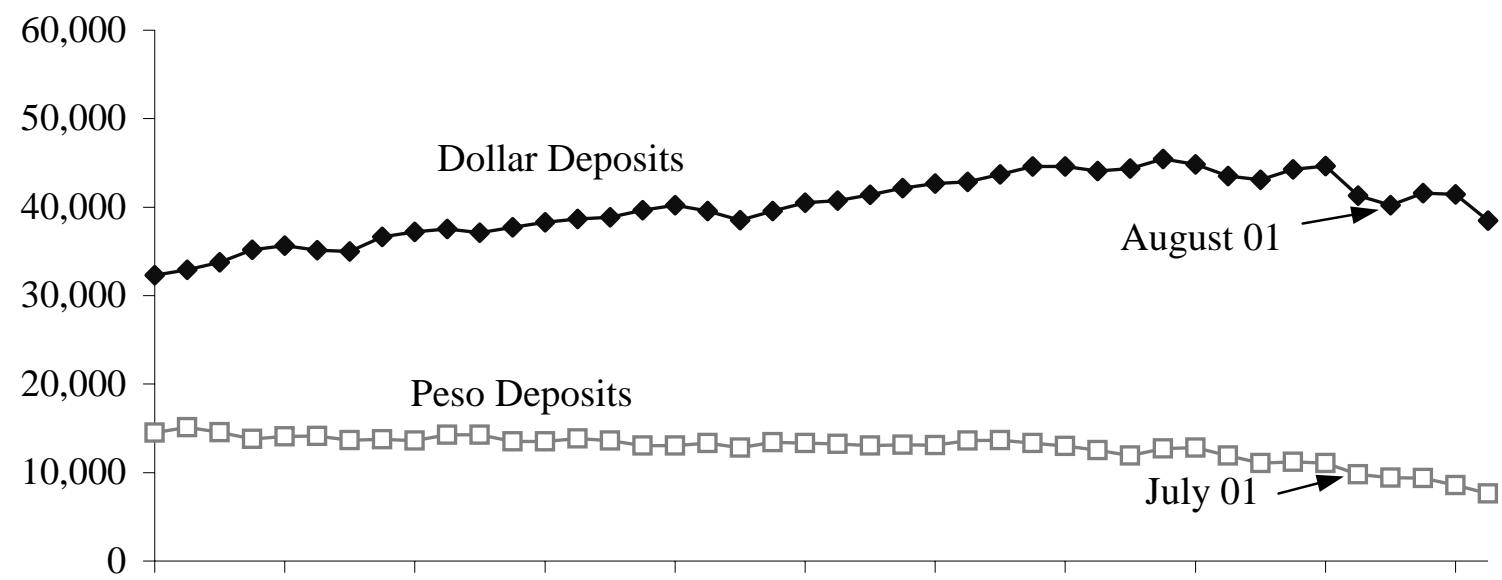

Jun-98 Oct-98 Feb-99 Jun-99 Oct-99 Feb-00 Jun-00 Oct-00 Feb-01 Jun-01 Oct-01

Basis Points

\section{Differential of Interest Rates}

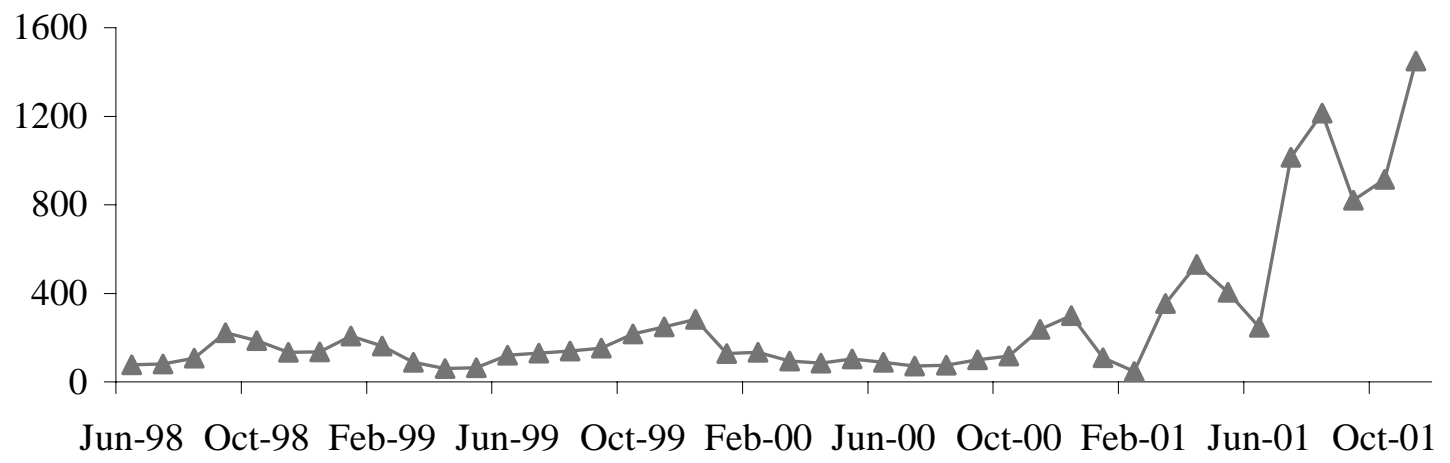

Deposits include private and public deposits. Differential of interest rates is defined as the spread between domestic interest rates for 30-day time deposits in pesos and U.S. dollars.

Source: Central Bank of Argentina 
Figure 9

Change in Private Deposits for 50 Largest Banks

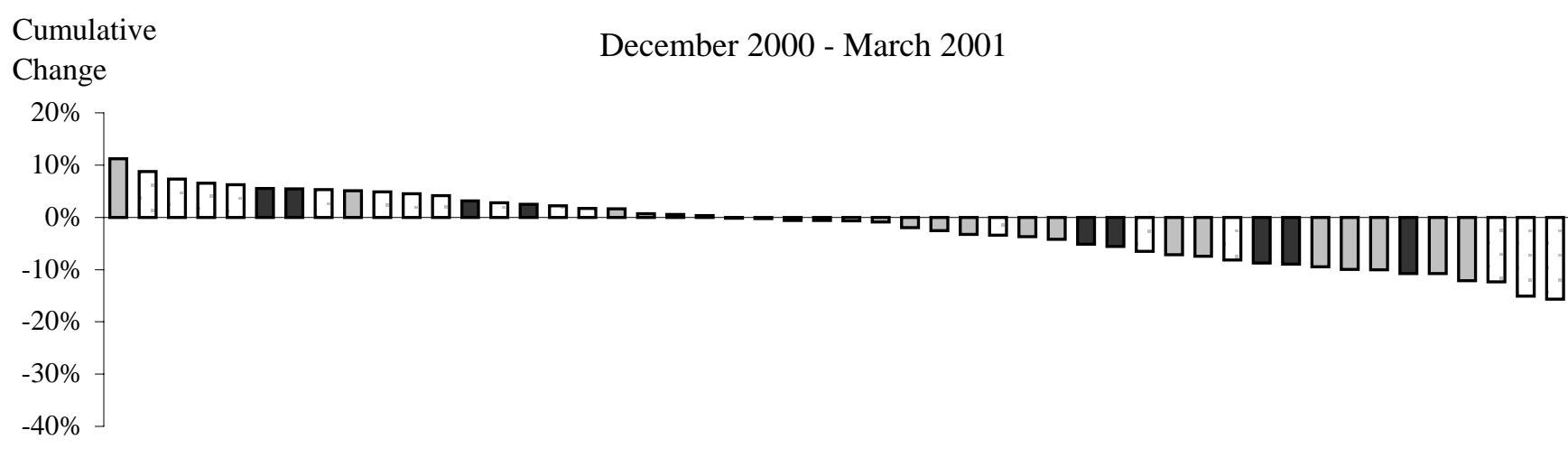

Cumulative

Change

December 2000 - July 2001

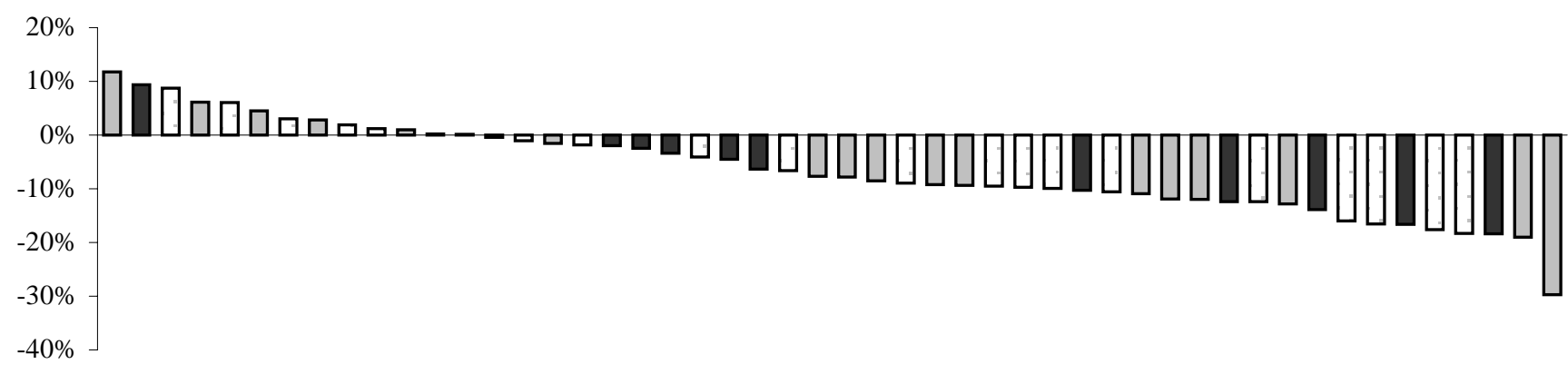

Cumulative

Change

December 2000 - November 2001

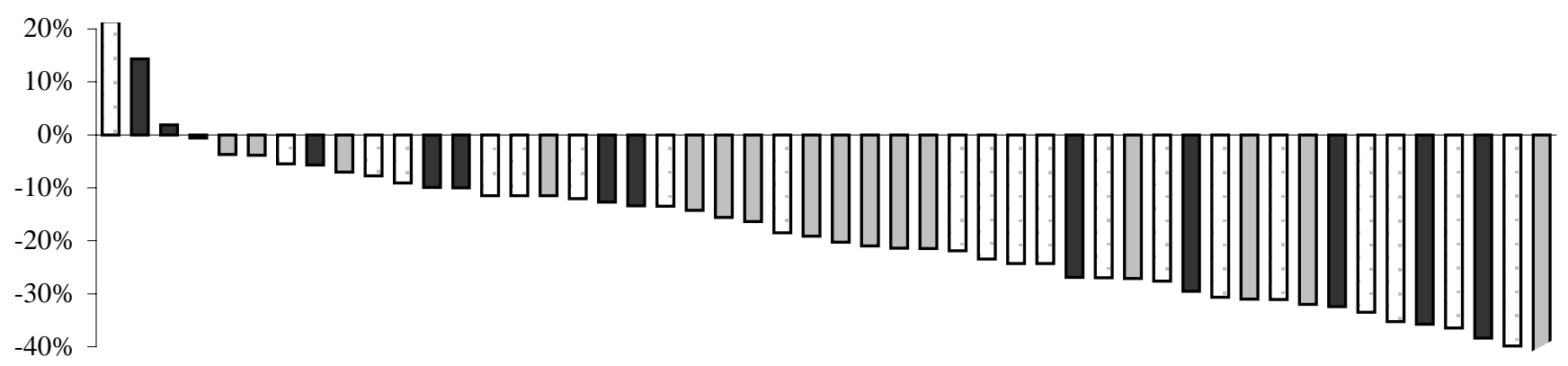

$\square$ Local private $\quad \square$ Foreign private $\quad \square$ Public

\begin{tabular}{lccccc}
\hline & \multicolumn{3}{c}{ Sample: Average Deposit Change (\%) } & & Banking System: Total \\
\cline { 2 - 4 } & Local private & Foreign private & Public & Total & \\
Deposit Change (\%)
\end{tabular}

The bars in the graphs represent the cumulative change in private deposits sorted from largest positive to largest negative change. A positive (negative) bar means that the bank gains (loses) deposits during the period. The different colors indicate whether the bank is local private, foreign private, or public. The 50 banks in the sample represent $98 \%$ of private deposits and $96 \%$ of total deposits in December 2000. In the bottom table, banking system total deposit change includes all banks in the system.

Source: Central Bank of Argentina 
Figure 10

Change in Private Deposits for 50 Largest Banks by Deposit Type

December 2000 - November 2001

Cumulative

Change

Peso Demand and Savings Deposits by Bank

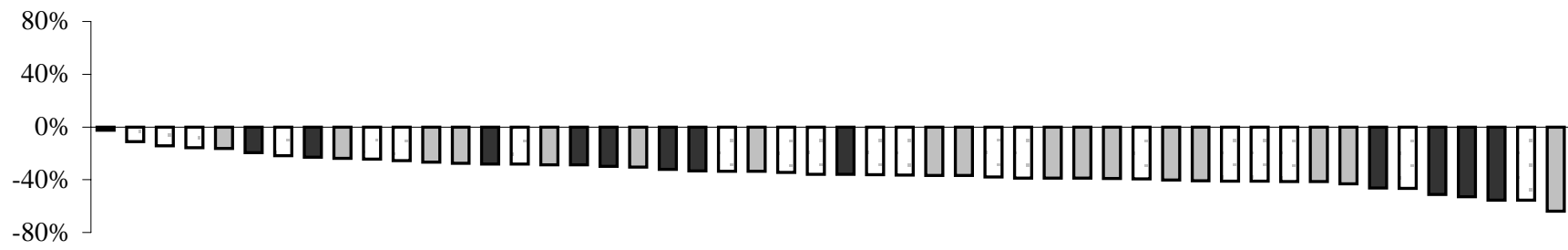

Cumulative

Change Dollar Demand and Savings Deposits by Bank

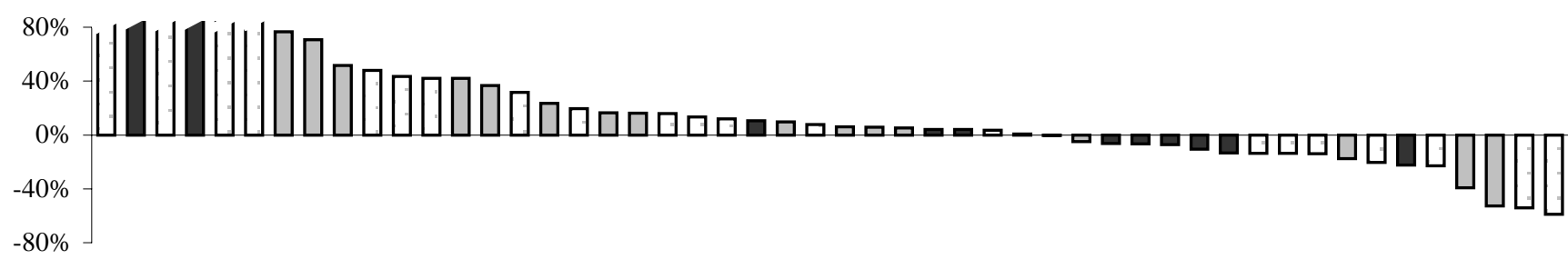

Cumulative

Change

Peso Time Deposits by Bank

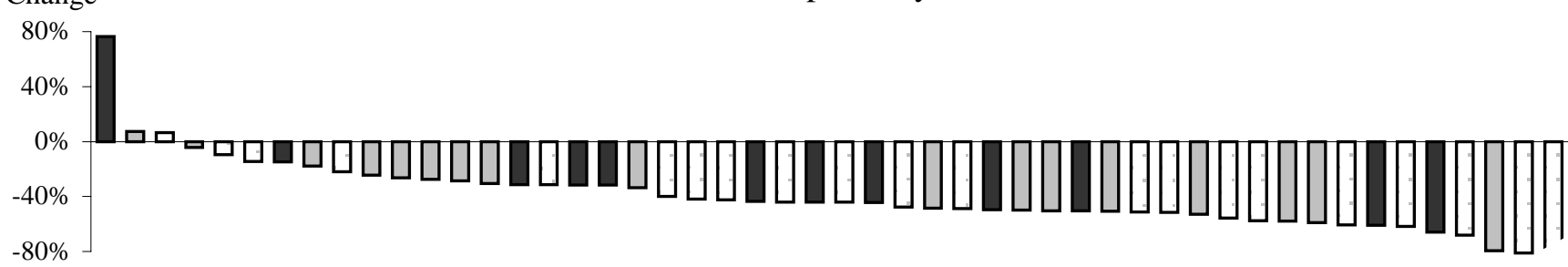

Cumulative

Change

$80 \%$

Dollar Time Deposits by Bank

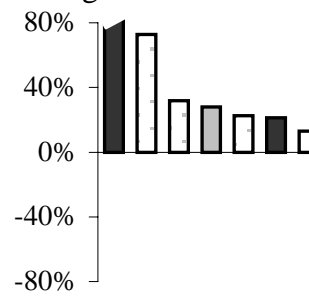

\begin{tabular}{|c|c|c|c|c|c|}
\hline & \multicolumn{4}{|c|}{ Sample: Average Deposit Change (\%) } & \multirow{2}{*}{$\begin{array}{c}\text { Banking System: Total } \\
\text { Deposit Change (\%) }\end{array}$} \\
\hline & Local private & Foreign private & Public & Total & \\
\hline Peso Demand and Savings Deposits & -31.5 & -35.7 & -36.3 & -34.1 & -36.0 \\
\hline Dollar Demand and Savings Deposits & 35.6 & 14.4 & 19.8 & 24.6 & 11.3 \\
\hline Peso Time Deposits & -45.2 & -37.3 & -32.7 & -39.5 & -37.7 \\
\hline Dollar Time Deposits & -6.5 & -13.0 & 7.5 & -5.4 & -13.9 \\
\hline
\end{tabular}

The bars in the graphs represent the cumulative change in private deposits sorted from largest positive to largest negative change. A positive (negative) bar means that the bank gains (loses) deposits during the period. The different colors indicate whether the bank is local private, foreign private, or public. The 50 banks in the sample represent $98 \%$ of private deposits and $96 \%$ of total deposits in December 2000. In the bottom table, banking system total deposit change includes all banks in the system.

Source: Central Bank of Argentina 


\section{Figure 11 \\ Financing Sources}

Millions of Dollars

\section{Federal Government}

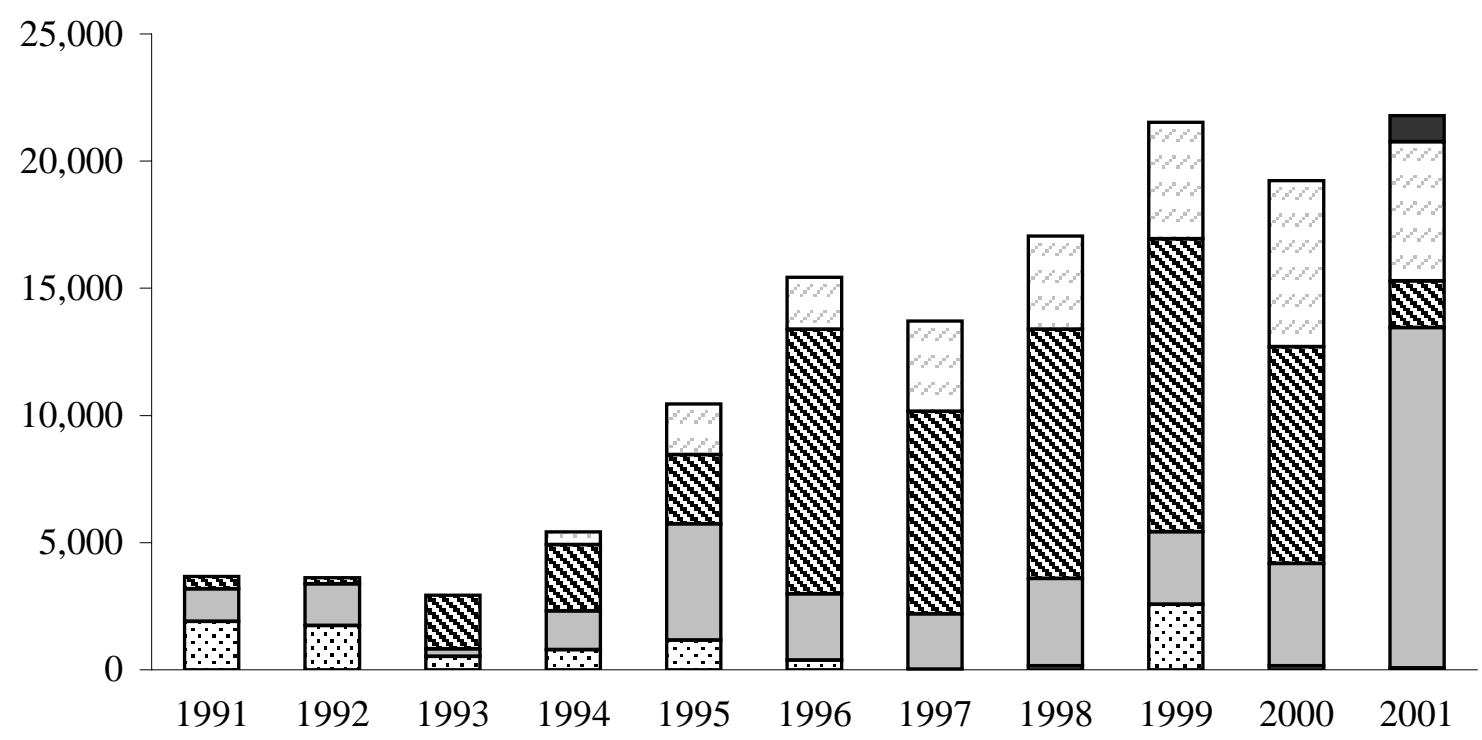

$\checkmark$ Privatizations and other capital income $\square$ International financial institutions ⿴囗大 International market, voluntary debt $\square$ Domestic market, voluntary debt $\square$ Lecop

\section{Province of Buenos Aires}

Millions of Dollars

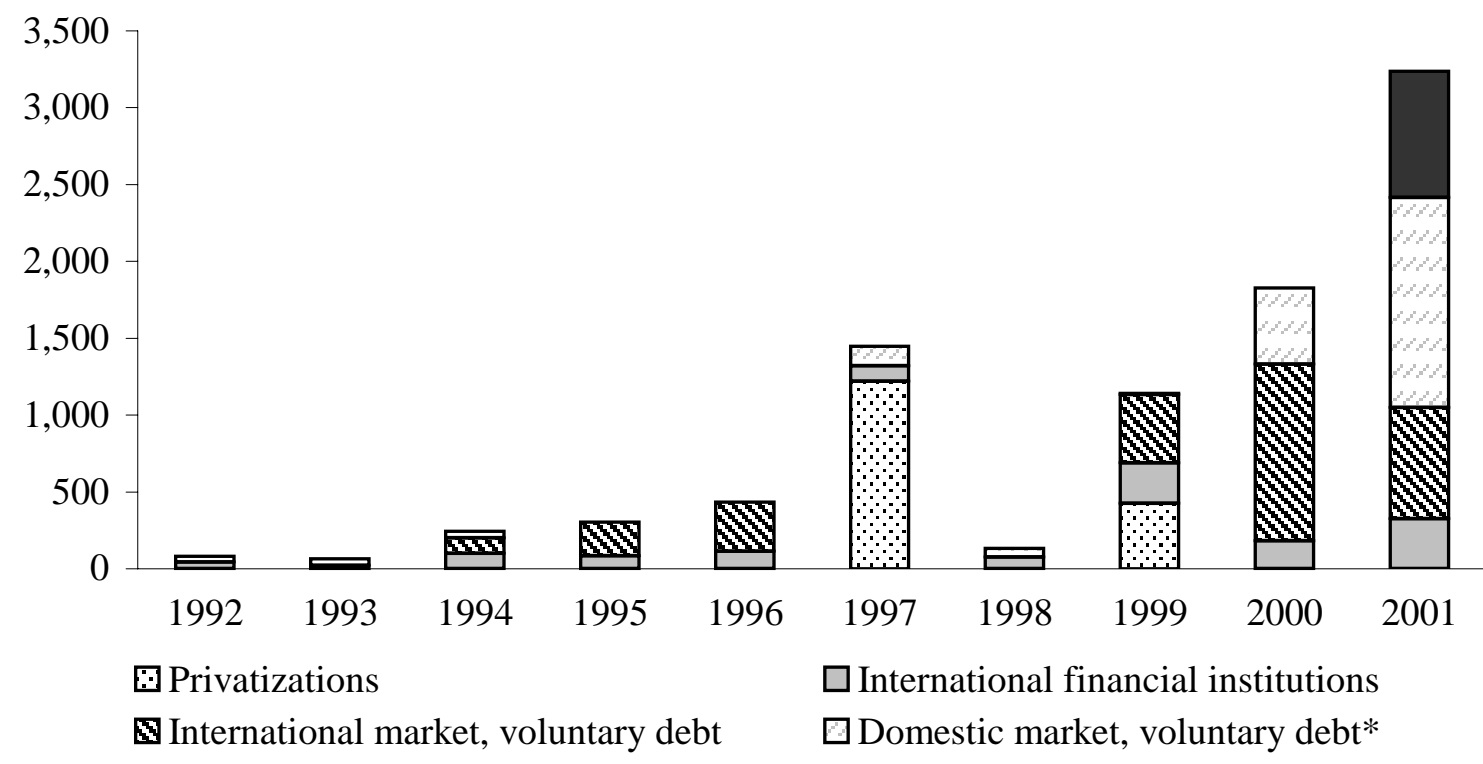

Patacones (I and II)

*Includes bank debt and national government financing.

Source: Central Bank of Argentina 
Figure 12

Ecuador: Bank Deposits and Dollarization

Index of Total Deposits

(=100 in January 2000)

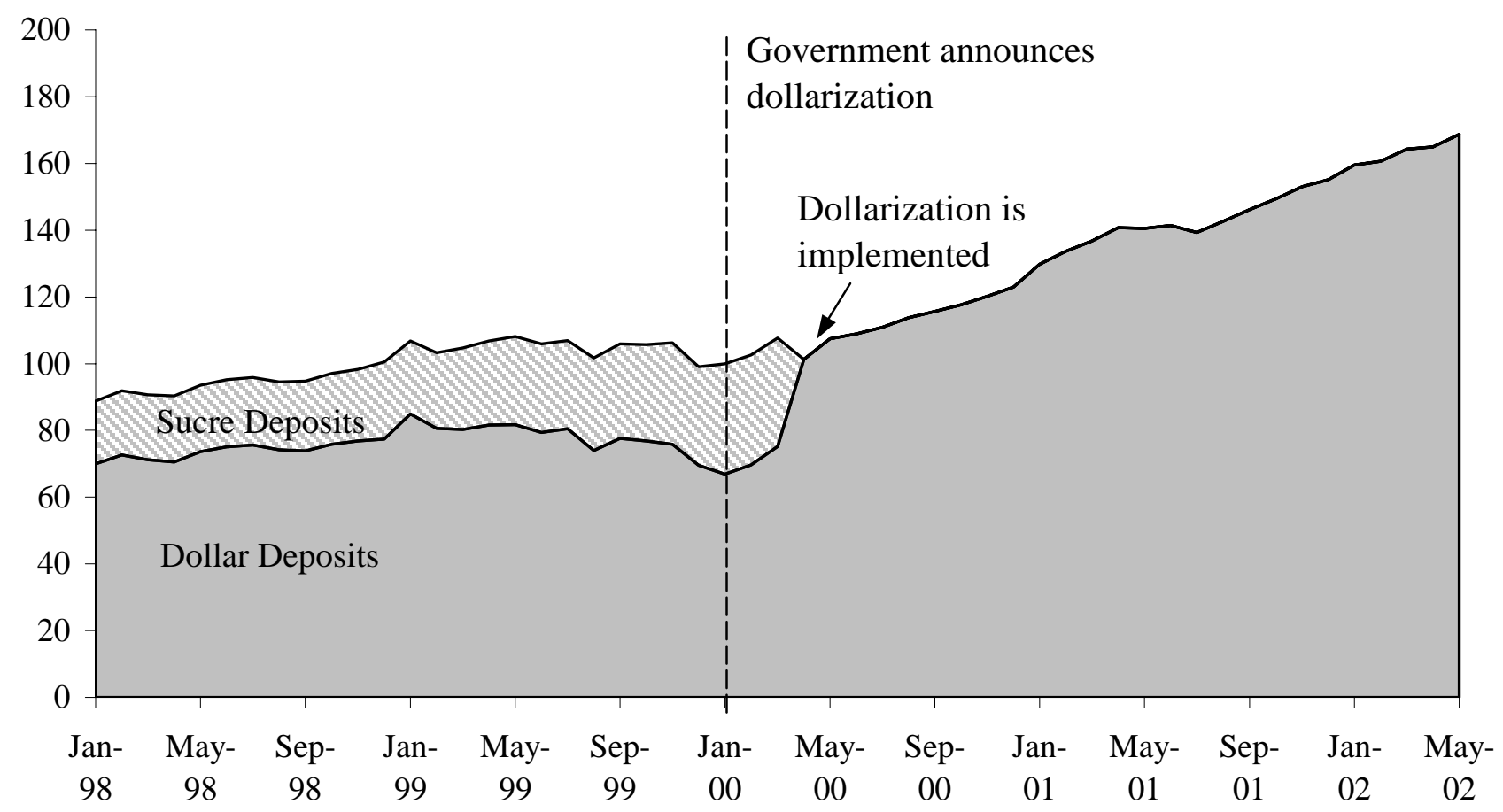

Dollarization was announced by President Mahuad in January 2000 but legally entered into effect only in March 2000, with the approval of the respective law, and after President Mahuad was replaced by President Gustavo Noboa. Sucre deposits are scaled by the conversion rate at which dollarization took place (25,000 sucres per dollar).

Source: Central Bank of Ecuador 
Figure 13

\section{Real Cash and Quasi-Monies in Circulation}

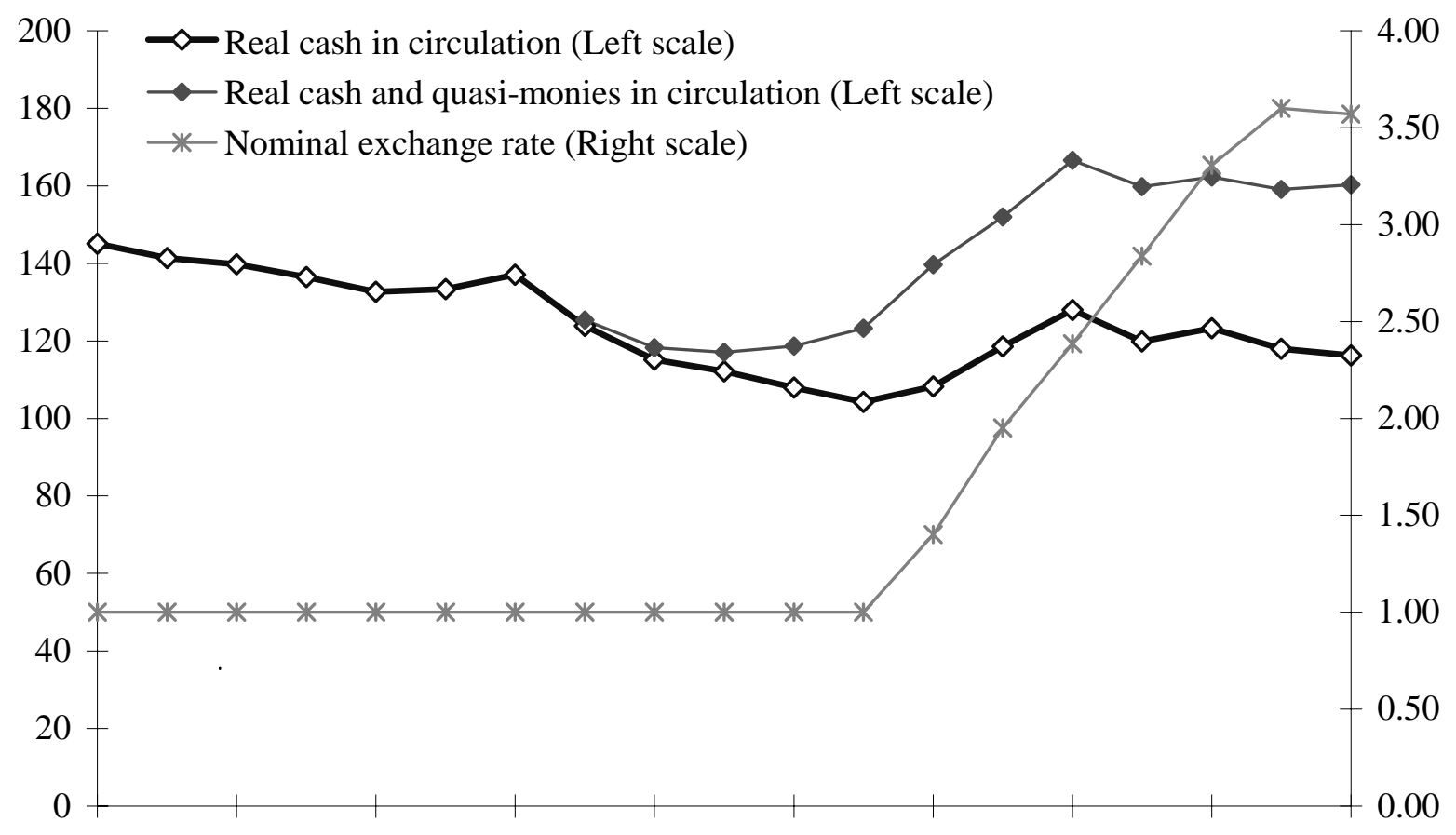

Jan-01 Mar-01 May-01 Jul-01 Sep-01 Nov-01 Jan-02 Mar-02 May-02 Jul-02

Quasi-monies only include Patacones and Lecop. Cash and quasi-monies in circulation are scaled by CPI. Figures are monthly averages.

Sources: Central Bank of Argentina and International Financial Statistics 
Table 1

Consolidation and Internationalization of the Banking System

\begin{tabular}{lrrr}
\hline & $\mathbf{1 9 9 4}$ & $\mathbf{1 9 9 8}$ & $\mathbf{2 0 0 0}$ \\
\hline Number of total banks & 166 & 104 & 89 \\
& & & \\
Foreign banks & 31 & 39 & 39 \\
$\quad$ Number of banks & 391 & 1,535 & 1,863 \\
Number of branches & 15 & 55 & 73 \\
Share of total assets $(\%)$ & & & 16 \\
& 32 & & 16 \\
\hline
\end{tabular}

Figures correspond to end-of-year values.

Source: Central Bank of Argentina 
Table 2

Selected Banking System Indicators

\begin{tabular}{lrrrr}
\hline & $\mathbf{1 9 9 7}$ & $\mathbf{1 9 9 8}$ & $\mathbf{1 9 9 9}$ & $\mathbf{2 0 0 0}$ \\
\hline Net Worth/Assets & 12.1 & 11.4 & 10.7 & 10.5 \\
Capital / Risk Weighted Assets & 18.1 & 17.6 & 18.6 & 21.2 \\
Non-Performing Loans/Total Loans (a) & 10.1 & 9.1 & 10.5 & 11.6 \\
Provisions/Total Loans & 6.2 & 5.5 & 6.1 & 7.3 \\
Provisions/Non-Performing Loans (a) & 60.9 & 60.4 & 58.4 & 63.3 \\
Systemic Core Liquidity (b) & 43.0 & 39.6 & 40.9 & 38.7 \\
Return on Equity before Provisions & 22.6 & 10.6 & 8.4 & 7.8 \\
Return on Equity after Provisions & 7.4 & -2.2 & -6.7 & -9.4 \\
Return on Assets after Provisions & 1.0 & -0.3 & -0.8 & -1.0 \\
Leverage Ratio (not in precent) & 6.1 & 7.3 & 7.7 & 8.3 \\
\hline
\end{tabular}

(a) Non-performing loans is defined as the sum of loans with problems, loans with high risk and non-recoverable loans.

(b) Defined as the ratio of international reserves of the central bank in foreign currency and other liquidity requirements held abroad by banks to total deposits.

Figures are in percent and correspond to end-of-year values.

Source: Central Bank of Argentina 
Table 3

Risk Indicators

\begin{tabular}{|c|c|c|c|}
\hline Date & Annual interest rate (\%) & Annual interest rate (\%) & Risk \\
\hline \multirow[t]{7}{*}{ 7/1/1993 } & Peso financing & Foreign-currency financing & \\
\hline & up to 24 & up to 18 & 1.00 \\
\hline & more than 24 to 27 & more than 18 to 21 & 1.20 \\
\hline & more than 27 to 30 & more than 21 to 24 & 1.40 \\
\hline & more than 30 to 33 & more than 24 to 27 & 1.60 \\
\hline & more than 33 to 36 & more than 27 to 30 & 1.80 \\
\hline & more than 36 to 39 & more than 30 to 33 & 2.00 \\
\hline \multirow[t]{7}{*}{ 2/1/1996 } & Peso financing & Foreign-currency financing & \\
\hline & up to 18 & up to 14 & 1.00 \\
\hline & more than 18 to 21 & more than 14 to 17 & 1.20 \\
\hline & more than 21 to 24 & more than 17 to 20 & 1.40 \\
\hline & more than 24 to 27 & more than 20 to 23 & 1.60 \\
\hline & more than 27 to 30 & more than 23 to 26 & 1.80 \\
\hline & more than 30 to 33 & more than 26 to 29 & 2.00 \\
\hline \multirow[t]{10}{*}{$1 / 1 / 2000$} & $\begin{array}{l}\text { Peso and foreign-currency financing: personal } \\
\text { loans, credit card financing, and overdrafts }\end{array}$ & Other financing & \\
\hline & up to 26 & up to 16 & 1.00 \\
\hline & more than 26 to 29 & more than 16 to 19 & 1.10 \\
\hline & more than 29 to 32 & more than 19 to 22 & 1.20 \\
\hline & more than 32 to 35 & more than 22 to 25 & 1.30 \\
\hline & more than 35 to 38 & more than 25 to 28 & 1.40 \\
\hline & more than 38 to 41 & more than 28 to 31 & 1.50 \\
\hline & more than 41 to 44 & more than 31 to 34 & 1.60 \\
\hline & more than 44 to 47 & more than 34 to 37 & 1.90 \\
\hline & more than 47 to 50 & more than 37 to 40 & 2.20 \\
\hline
\end{tabular}

Risk indicator is used in the calculation of the risk value of loans and other financing (excluding credit to financial institutions), which is then used to determine the capital requirements for credit risk. For higher interst rates other risk indicators apply.

Source: Central Bank of Argentina 
Table 4

Response of Peso and Dollar Deposits to Bank Risk Characteristics

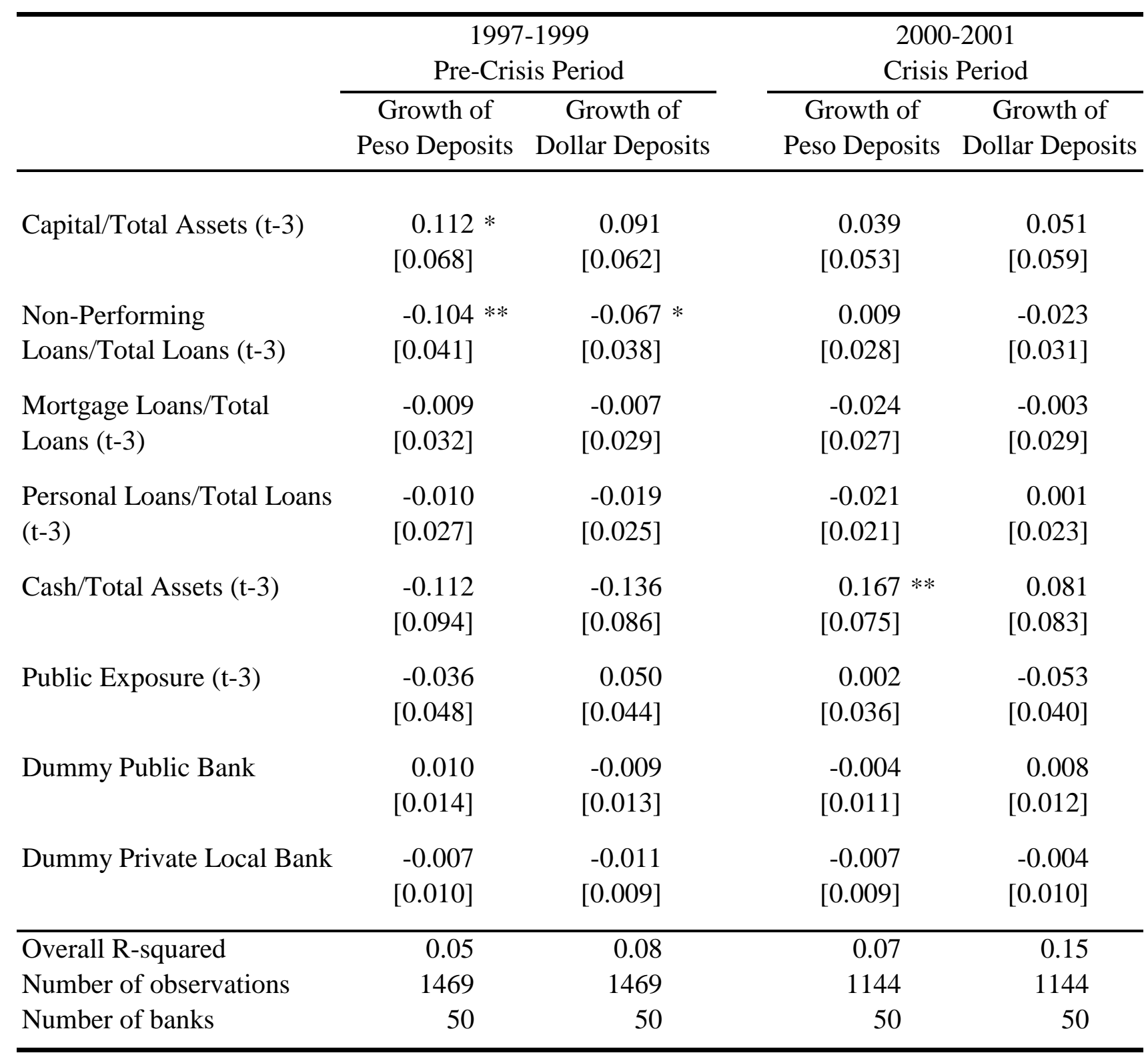

The table reports regressions of growth of deposits on bank fundamentals including time dummies. Public exposure is calculated as public bonds and loans to the public sector over total assets. Robust standard errors are in brackets. * significant at $10 \% ; * *$ significant at $5 \% ; * * *$ significant at $1 \%$. 
Table 5

Percentage of Variance Explained by Bank Risk Characteristics

\begin{tabular}{lcc}
\hline & $\begin{array}{c}1997-1999 \\
\text { Pre-Crisis Period }\end{array}$ & $\begin{array}{c}2000-2001 \\
\text { Crisis Period }\end{array}$ \\
\hline Growth of Peso & $19.2 \%$ & $3.6 \%$ \\
Deposits & {$[0.05]$} & {$[0.07]$} \\
Growth of Dollar & $10.3 \%$ & $1.2 \%$ \\
Deposits & {$[0.08]$} & {$[0.15]$} \\
\hline
\end{tabular}

The figures indicate the percentage of the overall R-squared explained by bank fundamentals, as a proportion of all the time varying variables. They are calculated as the R-squared of the regressions of growth of deposits on bank fundamentals over the R-squared of the regressions of growth of deposits on both bank fundamentals and time dummies. Overall R-squared is in brackets. 
Table 6

Private Deposit Withdrawal by Currency and Type December 2000 - November 2001

\begin{tabular}{|c|c|c|c|c|}
\hline & \multicolumn{2}{|c|}{$\begin{array}{l}\text { Growth of Peso Demand } \\
\text { and Savings Deposits }\end{array}$} & \multicolumn{2}{|c|}{$\begin{array}{l}\text { Growth of Peso } \\
\text { Time Deposits }\end{array}$} \\
\hline & (1) & (2) & (1) & (2) \\
\hline Currency Risk & $\begin{array}{l}-0.006 * * * \\
{[0.001]}\end{array}$ & $\begin{array}{l}-0.012 * * * \\
{[0.003]}\end{array}$ & $\begin{array}{l}-0.011 * * * \\
{[0.001]}\end{array}$ & $\begin{array}{l}-0.011 * * * \\
{[0.004]}\end{array}$ \\
\hline Country Risk & & $\begin{array}{r}0.003 \\
{[0.002]}\end{array}$ & & $\begin{array}{r}0.000 \\
{[0.002]}\end{array}$ \\
\hline $\begin{array}{l}\text { Country Risk*Public } \\
\text { Exposure }\end{array}$ & & $\begin{array}{r}0.003 \\
{[0.006]}\end{array}$ & & $\begin{array}{r}0.000 \\
{[0.008]}\end{array}$ \\
\hline $\begin{array}{l}\text { Overall R-squared } \\
\text { Number of observations } \\
\text { Number of banks }\end{array}$ & $\begin{array}{r}0.03 \\
1144 \\
50\end{array}$ & $\begin{array}{r}0.03 \\
1144 \\
50\end{array}$ & $\begin{array}{r}0.05 \\
1144 \\
50\end{array}$ & $\begin{array}{r}0.05 \\
1144 \\
50\end{array}$ \\
\hline \multirow{2}{*}{ Number of banks } & \multicolumn{2}{|c|}{$\begin{array}{l}\text { Growth of Dollar Demand } \\
\text { and Savings Deposits } \\
\end{array}$} & \multicolumn{2}{|c|}{$\begin{array}{l}\text { Growth of Dollar } \\
\text { Time Deposits }\end{array}$} \\
\hline & (1) & (2) & (1) & (2) \\
\hline Currency Risk & $\begin{array}{r}0.002 \\
{[0.003]}\end{array}$ & $\begin{array}{r}-0.006 \\
{[0.007]}\end{array}$ & $\begin{array}{l}-0.005 * * * \\
{[0.001]}\end{array}$ & $\begin{array}{r}-0.001 \\
{[0.002]}\end{array}$ \\
\hline Country Risk & & $\begin{array}{r}0.004 \\
{[0.004]}\end{array}$ & & $\begin{array}{l}-0.003 * * \\
{[0.001]}\end{array}$ \\
\hline $\begin{array}{l}\text { Country Risk*Public } \\
\text { Exposure }\end{array}$ & & $\begin{array}{r}0.000 \\
{[0.014]}\end{array}$ & & $\begin{array}{r}0.002 \\
{[0.003]}\end{array}$ \\
\hline Overall R-squared & 0.00 & 0.01 & 0.05 & 0.05 \\
\hline Number of observations & 1140 & 1140 & 1140 & 1140 \\
\hline Number of banks & 50 & 50 & 50 & 50 \\
\hline
\end{tabular}

The table reports regressions of growth of deposits on bank fundamentals and country and currency risks. Although included in the regressions, bank fundamentals are not reported in the table. Figures correspond to endof-period values. Standard errors are in brackets. * significant at 10\%; ** significant at 5\%; *** significant at $1 \%$. 
Table 7

Quasi-Monies in Circulation

(Millions of Argentine Pesos)

\begin{tabular}{llrr}
\hline & Denomination & December 2001 & March 2002 \\
\hline a. Federal government & Lecop & 1,039 & 2,543 \\
b. Provincial "own" securities & & 1,627 & 2,591 \\
$\quad$ 1. Buenos Aires & Patacón & 822 & 1,591 \\
2. Buenos Aires, City & Porteno & - & - \\
3. Catamarca & Ley 4748 & 26 & 31 \\
4. Chaco & Quebracho & 50 & 100 \\
5. Cordoba & Lecor & 200 & 300 \\
6. Corrientes & Cecaror & 193 & 185 \\
7. Entre Rios & Bonfe & 54 & 148 \\
8. Formosa & Bocanfor & 33 & 50 \\
9. Jujuy & Patacón & - & 6 \\
10. Mendoza & Petróm & - & - \\
11. La Rioja & Bono de Cancelación & 8 & 8 \\
12. Tucuman & Bocade & 98 & 173 \\
Total quasi-monies (a+b) & & 2,666 & 5,134 \\
Total quasi-monies & & 26.2 & 37.5 \\
(As percentage of pesos in circulation) & & & \\
\hline
\end{tabular}

Source: Ministry of Economy, Argentina 


\section{Appendix Table 1 \\ Post-1994 Banking System Strengthening}

Effective and ambitious financial sector reforms vigorously adopted in the second half of the 1990s were translated in a major consolidation and internationalization of the banking system (Table 1). The number of banks shrunk from 166 in 1994 to 89 in 2000. Banks exited not just through mergers and acquisitions but also through bank closures. The number of public banks decreased from 32 in 1994 to 15 in 2000, reflecting an aggressive privatization process of provincial banks. The number of branches of foreign-owned banks increased from 391 in 1994 to 1,863 in 2000, while the share of these banks in the system's assets rose from 15 to 73 percent.

This process was accompanied and underpinned by an acceleration in the pace of legal, regulatory, and supervisory innovations. The main improvements in the regulatory and contractual environment for the banking system are briefly described below.

\section{A quantum leap forward in a market-friendly approach to prudential oversight}

Much of this process was organized around the innovative BASIC program (in Spanish: $\mathrm{B}=$ bonos; $\mathrm{A}=$ auditoria; $\mathrm{S}=$ supervision consolidada; $\mathrm{I}=$ información; and $\mathrm{C}=$ calificadoras de riesgo). BASIC was an Argentine-bred approach, superimposed on internationally recognized CAMELS-based supervisory methodology, to enhance the complementarity between official and market monitoring. The "B" in BASIC emphasized the requirement on banks to issue subordinated debt so as to generate better price signals of bank risk. The "A" stood for a program to improve internal and external audits. The "S" referred to the implementation of consolidated supervision of financial conglomerates. The "I" reflected a major program to enhance the quality, depth, coverage, and dissemination of information-through higher reporting standards for financial statements, broader and easily accessible information on debtors, and more stringent information requirements on financial group structure and ownership. And the "C $\mathrm{C}$ " referred to the requirement on larger banks to have annual ratings by international rating firms. Partly as a result of the implementation of the BASIC program, it was broadly believed that Argentina in the late 1990s was near full compliance with the Basle Core Principles for Effective Banking Supervision.

Particularly noteworthy in the Argentine regulatory reform was the introduction of rigorous system of capital requirements, defined to absorb both credit and market risks, and significantly more stringent that the Basle minimum standard. The system featured various components. One component was minimum capital requirement for credit risk of 11.5 percent of risk-weighted loan exposures to the private sector, with variable weights within each loan class depending on the risk of individual loans, as measured by the interest rate charged on the loan. This ratio, moreover, was augmented by a factor for banks receiving lower CAMEL ratings. In addition, during 2000, positive risk weights were introduced for loans to the government and mark to market requirements were introduced for holdings of government bonds. Finally, capital requirements were set separately to absorb unexpected fluctuations in interest rates and in the prices of private sector securities.

Also noteworthy were the stringent liquidity requirements, high by international standards, and intended to work counter-cyclically-i.e., to be tightened during buoyant times and relaxed during times of systemic 


\section{A "best practice" scheme for troubled bank resolution}

After the Tequila, Argentina introduced key institutional innovations to enhance the bank exit framework, including Art. 35bis of the banking law-which created an efficient system for bank closure and resolution-and a privately managed limited deposit insurance scheme (SEDESA). This framework greatly contributed the consolidation of the banking system through the exit of unviable banks. Argentina became a salient case in the region where unviable banks (and not just small ones) were actually closed-between 1995 and 2000 about 20 banks were closed using the powers of Article 35bis.(1)

\section{Privatization of provincial banks}

Between 1994 and 1998, 16 provincial banks were privatized within a process that, though not perfect, was among the most aggressive and successful in the region.(2)

\section{Contingent repo facility}

This was an over-collateralized facility, structured in order to partially compensate for the virtual lack of a domestic lender of last resort and to strengthen the banking system's capacity to weather a liquidity crisis. The facility gave the BCRA the option to sell dollar-denominated Argentine government bonds to a consortium of reputable international banks, subject to a buy-back clause (with an embedded implicit interest rate). In 1999, the World Bank reinforced this facility by committing contingent funds to help meet margin calls in the event it was activated. By the end of the 1990s, the contingent repo line ensured the liquidity of about 10 percent of the system's deposits, in addition to the equivalent of nearly 20 percent of deposits already held in the form of liquid and safe FX assets (dollar cash and near-cash in the central bank and commercial banks).

\section{Improvements in the framework for creditor rights and corporate insolvency}

In 1995, Argentina enacted a new modern insolvency law that fostered a substantially improved system of corporate liquidation and rehabilitation. Similarly important reforms were implemented to improve the enforcement of secured and unsecured creditor rights. The World Bank assessment of Argentina's degree of compliance with international standards on insolvency and creditor rights found that, if one ignores the changes introduced most recently (in March 2002), the "permanent" framework for corporate insolvency and creditors rights is "largely consistent with the Principles."

(1) For further details see De la Torre (2000).

(2) A thorough assessment of the process and results of provincial bank privatization in Argentina can be found in World Bank (1999). 


\section{Appendix Table 2 Argentina's Via Crucis}

- President De la Rúa takes power in December 1999 when the country is already in recession and the public debt has reached high levels.

- The government tries to gain confidence, and thus restore growth, through fiscal adjustment.

- The "impuestazo" is implemented in January 2000. The new tax scheme includes, among other things, an increase in the taxation on consumer goods, an extension of VAT to health insurance and transportation, and an extension of the income tax base.

- The fiscal adjustment does not bring growth. Rather, the recession deepens and doubts about debt sustainability increase dramatically.

- The political weakness of the De la Rúa's administration becomes evident when vice president Carlos Alvarez resigns in October 2000.

- In December 2000, Minister Machinea negotiates a US\$40 billion package with international financial institutions and domestic financial institutions to extend the public debt maturity and try to ease fears of default. The deal implied a much lower amount of fresh funds, around US\$12 billion.

- The government's bet is that once these fears were eased, growth would resume, but growth does not pick up and Mr. Machinea resigns in March 2001.

- The newly appointed economy minister Lopez Murphy resigns after two weeks in office, upon strong opposition to the new fiscal austerity package he sent to Congress on March 16.

- Mr. Cavallo becomes economy minister once more. He is empowered by Congress with special powers and tries different, more direct, measures to revive growth. On April 16, 2001, he proposes to congress an amendment to the convertibility law, according to which the peso would be pegged to a basket consisting of US dollars and euros with equal weights, when the dollar-euro rate reaches 1:1. Congress approves the amendment in mid-June 2001. This change aims at better aligning the peso more with Argentina's trading partners.

- On April 25, 2001, the president of the central bank, Mr. Pedro Pou, resigns amid disagreements with Mr. Cavallo and other members of the government. Mr. Roque Maccarone replaces Mr. Pou.

- On July 10, 2001, the government, after being forced to pay 1,410 basis points over US Treasuries to place a short-term bond, announces a "zero deficit" rule.

- It thus becomes obvious that the government cannot tap capital markets without the debt exploding.

- To implement the zero deficit rule, the government pushes hard for an IMF-supported program. But to obtain it, the government needed an agreement with the provinces on tax revenue sharing.

- Mr. John Taylor, US Treasury under secretary, declares that there would not be any external help for Argentina until it can comply with its objective of a zero deficit.

- On October 26, 2001, the negotiations toward an agreement with the provinces on the distribution of tax revenues fail (again).

- On October 28, 2001, minister Cavallo starts negotiations to obtain resources from the IMF and the US Treasury to purchase collateral for new bonds to be issued in an exchange for the nearly US\$100 billion of local and external debt.

- On October 29, 2001, Mr. Cavallo defines the debt exchange operation as voluntary. The old debt would exchange for bonds paying seven percent per year and guarantee by taxes revenues. However, the IMF and US Treasury ask for compliance with the zero deficit and an agreement with the provinces on the tax revenue sharing before any kind of financial support is given. The negotiations last for more than a month. 
- On November 19, 2001, the IMF announces that it would not make any new disbursements to Argentina without being satisfied that the country has secured the goals previously defined.

- On December 2, 2001, the government announces measures restricting deposit withdrawals (the corralito). Withdrawals are limited to 250 pesos (dollars) per week per account.

- On December 19, 2001, Mr. Cavallo and all other ministers resigned.

- On December 20, 2001, President De la Rúa resigns and Mr. Ramon Puerta becomes interim president.

- On December 23, 2001, Mr. Rodriguez Saa, governor of one of the provinces, becomes the new interim president. His period is supposed to last 60 days, until elections are called on March 3, 2002. He declares the suspension of external debt payments for at least 60 days.

- On December 24, 2001, the government announces that a new fiat currency (i.e., without foreign-currency backing) would be created, the "argentino."

- On December 30, 2001, Mr. Rodriguez Saa resigns and the legislative assembly chooses Mr. Eduardo Duhalde as new president. He assumes power on January 2, 2002, and officially ends the currency board and announces the floating of the peso. 


\section{Universidad Torcuato Di Tella, Business School Working Papers}

\section{Working Papers 2003}

NN16 "Business Cycle and Macroeconomic Policy Coordination in MERCOSUR"

Martín Gonzalez Rozada (UTDT) y José Fanelli (CEDES).

No15 "The Fiscal Spending Gap and the Procyclicality of Public Expenditure"

Eduardo Levy Yeyati (UTDT) y Sebastián Galiani (UDESA).

No14 "Financial Dollarization and Debt Deflation under a Currency Board"

Eduardo Levy Yeyati (UTDT), Ernesto Schargrodsky (UTDT) y Sebastián Galiani (UDESA).

№13 " ¿ Por qué crecen menos los regímenes de tipo de cambio fijo? El efecto de los Sudden Stops", Federico Stuzenegger (UTDT).

№12 "Concentration and Foreign Penetration in Latin American Banking Sectors: Impact on Competition and Risk", Eduardo Levy Yeyati (UTDT) y Alejandro Micco (IADB).

№11 "Default 's in the 1990's: What have we learned?",

Federico Sturzenegger (UTDT) y Punan Chuham (WB).

№10 "Un año de medición del Indice de Demanda Laboral: situación actual y perspectivas",

Victoria Lamdany (UTDT) y Luciana Monteverde (UTDT)

N'09 "Liquidity Protection versus Moral Hazard: The Role of the IMF",

Andrew Powell (UTDT) y Leandro Arozamena (UTDT)

№8 "Financial Dedollarization: A Carrot and Stick Approach", Eduardo Levy Yeyati (UTDT)

No07 "The Price of Inconvertible Deposits: The Stock Market Boom during the Argentine crisis",

Eduardo Levy Yeyati (UTDT), Sergio Schmukler (WB) y Neeltje van Horen (WB)

NN06 "Aftermaths of Current Account Crisis: Export Growth or Import Contraction?",

Federico Sturzenegger (UTDT), Pablo Guidotti (UTDT) y Agustín Villar (BIS)

No5 "Regional Integration and the Location of FDI",

Eduardo Levy Yeyati (UTDT), Christian Daude (UM ) y Ernesto Stein (BID)

N04 "A new test for the success of inflation targeting",

Andrew Powell (UTDT), Martin Gonzalez Rozada (UTDT) y Verónica Cohen Sabbán (BCRA)

No03 "Living and Dying with Hard Pegs: The Rise and Fall of Argentina's Currency Board",

Eduardo Levy Yeyati (UTDT), Augusto de la Torre (WB) y Sergio Schmukler (WB)

No02 "The Cyclical Nature of FDI flows",

Eduardo Levy Yeyati (UTDT), Ugo Panizza (BID) y Ernesto Stein (BID) 
№1 "Endogenous Deposit Dollarization",

Eduardo Levy Yeyati (UTDT) y Christian Broda (FRBNY)

\section{Working Papers 2002}

№15 "The FTAA and the Location of FDI",

Eduardo Levy Yeyati (UTDT), Christian Daude (UM ) y Ernesto Stein ( BID)

No14 "Macroeconomic Coordination and Monetary Unions in a N-country World: Do all Roads

Lead to Rome?"

Federico Sturzenegger (UTDT) y Andrew Powell (UTDT)

№13 "Reforming Capital Requirements in Emerging Countries"

Andrew Powell (UTDT), Verónica Balzarotti (BCRA) y Christian Castro (UPF)

№12 "Toolkit for the Analysis of Debt Problems", Federico Sturzenegger (UTDT)

№11 "On the Endogeneity of Exchange Rate Regimes",

Eduardo Levy Yeyati (UTDT), Federico Sturzenegger (UTDT) e lliana Reggio (UCLA)

№10 "Defaults in the 90's: Factbook and Preliminary Lessons", Federico Sturzenegger (UTDT)

No09 "Countries with international payments ' difficulties: what can the IMF do?"

Andrew Powell (UTDT)

NN08 "The Argentina Crisis: Bad Luck, Bad Management, Bad Politics, Bad Advice",

Andrew Powell (UTDT)

N07 "Capital Inflows and Capital Outflows: Measurement, Determinants, Consequences",

Andrew Powell (UTDT), Dilip Ratha (WB) y Sanket Mohapatra (CU)

No06 "Banking on Foreigners: The Behaviour of International Bank Lending to Latin America, 1985-2000",

Andrew Powell (UTDT), María Soledad Martinez Peria (WB) y Ivanna Vladkova ( IMF)

No05 "Classifying Exchange Rate Regimes: Deeds vs. Words"

Eduardo Levy Yeyati (UTDT) y Federico Sturzenegger (UTDT)

NN04 "The Effect of Product Market Competition on Capital Structure: Empirical Evidence from the

Newspaper Industry", Ernesto Schargrodsky (UTDT)

N03 "Financial globalization: Unequal blessings",

Augusto de la Torre (World Bank), Eduardo Levy Yeyati (Universidad Torcuato Di Tella) y Sergio

L. Schmukler (World Bank)

N02 "Inference and estimation in small sample dynamic panel data models",

Sebastian Galiani (UdeSA) y Martin Gonzalez-Rozada (UTDT)

№1 "Why have poverty and income inequality increased so much? Argentina 1991-2002",

Martín González-Rozada, (UTDT) y Alicia Menendez, (Princeton University). 